\title{
Estimates of the Term Premium on Near-dated Federal Funds Futures Contracts
}

\author{
J. Benson Durham* \\ Division of Monetary Affairs \\ Board of Governors of the Federal Reserve System \\ Mail Stop 71 \\ $20^{\text {th }}$ and C Streets \\ Washington, DC 20551 \\ j.benson.durham@frb.gov
}

(202) 452-2896

\begin{abstract}
This paper examines estimates of the term premium on federal funds futures rates, with a focus on near-dated contracts and therefore the more immediate policy horizon. The first set of methods assumes that the term premium is constant over time. Under this framework, calculations that use survey data to proxy for forecast errors produce more intuitive results than estimates based on the restrictive assumption that forecast errors average to zero over the sample. The second set of methods allows the term premium to vary over time, but the results based on the term structure of near-dated federal funds futures contracts are highly volatile, which perhaps reflects numerous technical factors in the underlying federal funds market. Finally, under an asset-pricing approach, the CAPM suggests that the risk premium on federal funds futures is either less than or equal to zero, while APT indicates that it can be positive.
\end{abstract}

\footnotetext{
${ }^{*}$ The author thanks Antulio Bomfim, Emily Cauble, Jim Clouse, Darrel Cohen, Jonathan Wright and other seminar participants at the Federal Reserve Board for helpful comments. Emily Cauble also provided outstanding research assistance. Any remaining errors are solely the author's, and the views expressed in this paper do not necessarily reflect those of the Board of Governors of the Federal Reserve System or any member of its staff.
} 


\section{Introduction}

Previous research suggests that federal funds futures contracts most closely reflect market expectations about near-term monetary policy compared to other financial assets. ${ }^{1}$ Therefore, policymakers can examine the term structure of implied rates on these derivatives to help assess policy expectations and therefore interest rate forecasts implicit in other asset prices. ${ }^{2}$ But, the possible presence of a term premium in federal funds future contracts complicates extracting precise estimates of expected Federal Reserve action. Indeed, the market-implied expected policy path is considerably sensitive to assumptions about the term premium and its relation to time to maturity.

This paper outlines several estimates of the term premium on implied federal funds futures rates under alternative assumptions and focuses on near-term policy expectations, primarily the horizon within the subsequent three FOMC meetings. ${ }^{3}$ The first set of estimates assumes that the term premium is constant over time. Within this set, estimates based on monthly and daily data either assume that market participants' forecast errors average to zero over the sample or use survey data to proxy for forecast errors directly. While each method has notable shortcomings, the survey-based calculation using daily data that relaxes the assumption that forecast errors average to zero is more consistent with common priors regarding the magnitude of the term premium.

The second set of estimates uses simple decompositions of the term structure of implied rates on near-dated federal funds futures contracts to estimate a time-varying term premium.

\footnotetext{
${ }^{1}$ For example, Gürkaynak et al. (2002) examine the predictive power of a number of market-based measures of policy expectations and find that since 1994, federal funds futures rates most accurately forecast the federal funds rate out to several months. They also find that eurodollar futures rates perform better than many other instruments at longer horizons.

${ }^{2}$ For a more detailed description of federal funds futures markets see Krueger and Kuttner (1996), Söderström (2001), or Moore and Austin (2002).

${ }^{3}$ See Sack (2002) for details on extracting the path of policy expectations out to two years using federal funds and eurodollar futures contracts.
} 
These results, even given smoothed series based on monthly medians, are highly volatile, which likely reflects omitted idiosyncratic technical factors in the underlying funds market. Moreover, while one might expect term premiums at long and short horizons to be positively correlated, these estimates do not correlate closely with an alternative estimate of the term premium that uses the term structure of implied rates on eurodollar futures contracts that expire between four and five years ahead (Sack, 2002).

In addition, this paper also briefly examines an asset-pricing approach using an estimate of excess returns on long federal funds futures positions. Standard empirical applications of the capital asset pricing model (CAPM) and arbitrage pricing theory (APT) also provide evidence regarding the sign and magnitude of the risk premium. According to the CAPM, the covariance between returns on federal funds futures and a proxy for the market portfolio is either negative or statistically insignificant from zero, which in turn implies that the risk premium is less than or equal to zero. But APT, an alternative asset-pricing model, fits the data better and suggests that the risk premium can be positive.

The next section outlines estimates of the term premium that do not vary over time.

Section 3 examines an alternative calculation of a time-varying term premium based on the term structure of federal funds futures rates. Section 4 applies the CAPM and APT to excess returns on federal funds futures, and Section 5 concludes.

\section{Constant Term Premium Estimates}

The key assumption behind this first set of estimates is that the term premium is constant over time. These include calculations using monthly data on the underlying federal funds market that follow the expectations hypothesis as well as tests of bias and rationality in federal funds 
futures forecasts. Also, an estimate using daily futures data that closely reflects the expectations hypotheses and the no arbitrage condition provides greater leverage to estimate the functional relation between the term premium and time to maturity. The final estimate uses daily futures data and weekly survey data to relax the assumption that futures market forecast errors average to zero over a finite sample.

\subsection{The Expectations Hypothesis: Monthly Data on Term and Effective Federal Funds Rates}

An application of the expectations hypothesis of the term structure using data on the underlying federal funds market suggests that the term premium is positive and that it increases with maturity. Similar to Rudebusch (1995), this section examines two types of evidence. The first type regards the predictive ability of spreads between the yields of two securities where the maturity of the longer-dated security is twice that of the shorter-dated security. Under this rubric, the analyses examine such spreads on monthly term federal funds rates from one to 12 months. The second type examines the ability of spreads between an overnight rate and an $n$ month rate to predict future changes in the overnight rate. Therefore, the analyses alternatively include the one- to six-month spread of term federal funds over the overnight effective federal funds rate.

With respect to the first method, the expectations hypothesis implies that the current yield at time $t$ on term federal funds over $2 \times n$ months, $r_{2 n, t}^{t f f}$, equals the average of the actual and expected $n$-month yields plus a (constant) premium, as in

$$
r_{2 n, t}^{t f f}=\frac{r_{n, t}^{t f f}+E_{t} r_{n, t+1}^{t f f}}{2}+p_{n, t+1}^{e}
$$

If expectations are rational, then 


$$
E_{t} r_{n, t+1}^{t f f}=r_{n, t+1}^{t f f}-\varepsilon_{t+1}
$$

which says that the expectation at time $t$ for the $n$-period yield at $t+1, E_{t} r_{n, t+1}^{t f f}$, is equal to the realized yield at $t+1, r_{n, t+1}^{t f f}$, minus a forecast error, $\varepsilon$. Substituting (2) into (1), subtracting $r_{n, t}^{t f f}$ from both sides, and rearranging produces the estimation equation

$$
\frac{r_{n, t+1}^{t f f}-r_{n, t}^{t f f}}{2}=-p_{n, t+1}^{e}+\beta\left(r_{2 n, t}^{t f f}-r_{n, t}^{t f f}\right)+\frac{\varepsilon_{t+1}}{2},
$$

where the null hypothesis under rational expectations is that $\beta=1$, the intercept is the negative of the term premium, and OLS notably forces the mean of $\varepsilon_{t+1}$ to zero. ${ }^{4}$

Monthly data for estimation of (3) cover the May 1993 - March 2003 period, and as Model 1 in Table 1 suggests, the term premium using the spread between the two- and onemonth term federal funds rates $(n=1)$ is about 4.7 basis points, which is safely statistically significant. Also, these results are consistent with the expectations hypothesis that $\beta=1$, as the t-statistic for rejecting the $\mathrm{H} 0$ that $\beta \neq 1$ is 0.047 . Consideration of alternative values of $n$ gives some indication of how the term premium changes with the time to maturity. For example, with $n=2$, Model 2 indicates that the two-month premium is about 8.7 basis points, a four basis point increase from one to two months. Similarly, Models 3-6, which along with Model 2 notably are each consistent with the expectations hypothesis that $\beta=1$, suggest that the premium increases 4.3 basis points (to 13.0 basis points) from two to three months, 5.9 basis points (to 18.9 basis points) from three to four months, 3.3 basis points (to 22.2 basis points) from four to five

\footnotetext{
${ }^{4}$ See Rudebusch (1995) for a summary of results from the empirical literature on a variety of short-term interest rates.
} 
months, and 1.2 basis points (to 23.4 basis points) from five to six months, respectively.

Therefore, the term premium increases with the maturity of the term federal funds rate and, at least given these six observations, seems to be positive and to increase at a decreasing rate with maturity. ${ }^{5}$

Regarding the second type of evidence using term and daily effective federal funds rates, the expectations hypothesis suggests that the term federal funds rate, $r^{t f f}$, over $n$ periods (days) observed at time $t$ should equal the weighted average of expected overnight rates from $t+2$ to $t$ $+n+1$ plus a term premium, $p .^{6}$

$$
r_{n, t}^{t f f}=\frac{1}{n}\left[E_{t} \sum_{i=0}^{n-1} r_{1, t+2+i}^{e f f}\right]+p_{n, t+n+1}
$$

Similar to (2), if expectations are rational, then

$$
E_{t} \sum_{i=0}^{n-1} r_{1, t+2+i}^{e f f}=\sum_{i=0}^{n-1} r_{1, t+2+i}^{e f f}-\varepsilon_{n, t+n+1}
$$

which says the expectation of future overnight rates at $t$ is equal to the realized overnight rates over $t+2$ to $t+n+1$ minus a forecast error, $\varepsilon$. Substituting (5) into (4), subtracting the overnight funds rate at $t, r_{1, t}^{\text {eff }}$, from both sides, and rearranging produces the estimation equation

$$
\frac{1}{n} \sum_{i=0}^{n-1} r_{1, t+2+i}^{e f f}-r_{1, t}^{e f f}=-p_{n, t+n+1}+\beta\left(r_{n, t}^{t f f}-r_{1, t}^{e f f}\right)+\frac{\varepsilon_{n, t+n+1}}{n}
$$

\footnotetext{
${ }^{5}$ This function form is similar to the estimates of the yield curve using a two-factor in Bomfim (2003).

${ }^{6}$ In the term federal funds market, the $n$-month term federal funds rate quoted on day $t$ refers to the period from day $t+2$ of the current month to day $t+2$ of the following month.
} 
Table 2 presents these results using the overnight and term federal funds rates from one to six months to maturity, given all available data from May 1993 through March 2003. Model 1, which examines the spread between the one-month term and the effective federal funds rates, suggests that the term premium is positive, at 16.9 basis points, and safely statistically significant. However, the data at this horizon reject the expectations hypothesis that $\beta=1$. Models 2-6, which in contrast are consistent with the hypothesis that $\beta=1$, give some indication of how the term premium increases with maturity. For example, the term premium increases 6.8 basis points (to 23.7 basis points) from one to two months, 4.2 basis points (to 27.9 basis points) from two to three months, 4.2 basis points (to 32.1 basis points) from three to four months, 4.4 basis points (to 36.5 basis points) from four to five months, and 5.5 basis points (to 41.0 basis points) from five to six months, respectively. Therefore, given these six estimates of the term premium at different maturities, the term premium per month seems to be positive.

\subsection{Tests of Bias and Market Efficiency on Monthly Futures Data}

These tests of the expectations hypothesis using the underlying federal funds market of course do not address the futures market directly. However, an empirical test of the efficient markets hypothesis using federal funds futures forecasts also indicates that the term premium is positive and crudely suggests that it increases with time to maturity. Following Krueger and Kuttner (1996), arbitrage by risk-neutral investors implies no predictable profit opportunities, and therefore the federal funds futures rate at time $t$ for the settlement period $t+n$ should equal the average of expected realized effective federal funds rates, as in

$$
r_{t+n, t}^{f f f}-E_{t}\left(\frac{1}{n} \sum_{t=1}^{n} r_{t}^{e f f}\right)=0
$$


An empirical application of this expression follows

$$
\bar{r}_{t+n, t}^{f f f}-\bar{r}_{t+n, t+n}^{e f f}=\alpha+\beta X_{t-1}+\varepsilon_{t+n}
$$

where $\bar{r}^{f f f}$ is the average daily futures rate during month $t$ for settlement at $t+n, \bar{r}^{\text {eff }}$ is the average effective federal funds rate during the settlement month $t+n, \mathbf{X}$ is a set of variables that might predict the effective federal funds rate in addition to the futures rate (if the futures market is not rational), $\alpha$ is the bias in the forecast (or term premium), and $\varepsilon$ is the forecast error, which again OLS estimation notably forces to zero. If the futures market forecast is unbiased, then $\alpha=$ 0. Also, if futures rates incorporate all available information used for predicting the funds rate, then such forecasts are rational, and therefore $\beta=0$.

Given data from June 1989 - November 1994, Krueger and Kuttner (1996) find that $\alpha$ is positive and statistically significant. Specifically, the premium or positive bias is equal to about 6.1 basis points with $n=1$ and 12.1 basis points with $n=2$. Also, very few variables in $\mathbf{X}$ are significant within their sample, and significant factors within sample only marginally improve out-of-sample forecasts. Therefore, they conclude that the futures market incorporates virtually all publicly available information.

Table 3 expands their analysis and includes regressions using data from October 1988 March 2003 that follow (8) where $\mathbf{X}$ is empty. Model 1 indicates that the bias is equal to about 5.0 basis points at a one-month horizon, and therefore the term premium is positive and statistically significant. Similar to Tables 1-2, estimates for alternative horizons (values of $n$ ) are noteworthy because they give some indication of the relation between the premium and the forecast horizon. For example, Models 2-4 in Table 3 suggest that the premium increases approximately 4.8 basis points (to 9.8 basis points) from one to two months, 6.1 basis points (to 
15.9 basis points) from two to three months, and 7.5 basis points (to 23.4 basis points) from three to four months. Therefore, the premium or bias seems to increase with the forecast horizon at an increasing rate. But, similar to the estimates in Tables 1-2, there are few observations to determine the precise functional relation with time to maturity.

Some commentary on the efficiency of the futures market is instructive. Within sample tests for variables in $\mathbf{X}$ largely suggest, similar to Krueger and Kuttner (1996), that the federal funds futures market is largely efficient. According to the results in Table 4, most variables in $\mathbf{X}$, perhaps most notably the dummy variable for whether the forecasted month includes an FOMC meeting (Model 9), are not statistically significant, and the $\mathrm{R}^{2}$ values for each regression are very small, which implies that none of the factors has considerable predictive power. However, the regressions suggest that the market does not incorporate all information related to contemporaneous changes in the target federal funds rate (Model 8), a dummy for monetary policy tightening regimes (Model 10), one-month lagged payroll employment growth (Model 12), or one-month lagged changes in unemployment insurance claims (Model 13).

\subsection{Daily Data: Forecast Errors Average to Zero}

Given the monthly frequency of the data, Tables 1-3 provide few observations for estimating the relation between the term premium and time to maturity. However, daily data produce a greater number of observations. To exploit higher frequency data, similar to previous estimates consistent with the expectations and efficient markets hypothesis, suppose

$$
r_{t+n, t}^{f f f}=E_{t} r_{t+n}^{\text {eff }}+p_{t+n, t}^{e}
$$


where the federal funds futures rate, $r^{f f f}$, at time $t$ that expires $n$ periods ahead differs from the expected settlement rate, $\mathrm{r}^{\text {eff }}$, by a premium, $p^{e}$. Note that neither term on the right-hand-side is observable. But, at time $T$, where $T \geq t+n$, one can use the realized settlement effective funds rate, $\bar{r}_{t+n}^{e f f}$, and the forecast error, $e$, to approximate $E_{t} r^{e f f}{ }_{t+n}$, as in

$$
\mathrm{E}_{\mathrm{t}} \mathrm{rff}_{\mathrm{t}+\mathrm{n}}^{\mathrm{en}}=\bar{r}_{t+n}^{e f f}+\varepsilon_{\mathrm{t}+\mathrm{n}}
$$

Substituting (10) into (9) and solving for $p^{e}$ follows

$$
\mathrm{p}_{\mathrm{t}, \mathrm{t}+\mathrm{n}}^{\mathrm{e}}=\mathrm{r}_{\mathrm{t}}^{\mathrm{fff}}-\bar{r}_{t+n}^{\text {eff }}-\varepsilon_{\mathrm{t}+\mathrm{n}} \text {. }
$$

Therefore, wholly consistent with the applications of the expectations hypothesis and tests of bias and rationality, if one assumes that forecast errors sum to zero over the sample, then the term premium for a given maturity is simply the difference between federal funds futures rates and realized settlement rates, both of which are observable by time $T$. Again, this is quite similar to the OLS estimations of (3) and (8), which force the average forecast error to zero. ${ }^{7}$

Given the history of federal funds futures rates from October 4, 1988 through March 31, 2003 and contracts out to five months, an empirical calculation to estimate the relation between the term premium and time to maturity using this general framework and daily data follows these steps. First, calculate all values of $p^{e}$ for each day in the sample. Therefore, with five contracts, there are five different estimates of $p^{e}$ each trading day. Second, calculate the mean of $p^{e}$ for

\footnotetext{
${ }^{7}$ The assumption that forecast errors average to zero over time does not preclude the possibility that forecast errors might be smaller during periods when the target federal funds rate remains largely unchanged relative to a sustained tightening or easing episodes. The assumption is also not inconsistent with the possibility that investors undershoot (overshoot) the beginning (endings) of either tightening or easing cycles. Rather, the assumption is that market participants systematically neither over- nor under-estimate increases or reductions in the target. (Moore and Austin [2002] indeed generally find that "forecast errors," which in their terminology is the difference between futures and settlement rates, are greater during periods of increases and decreases in the target.)
} 
each number of days to maturity (DTM) in the sample, from 1 to 150 days. ${ }^{8}$ These means are analogous to the intercept of (8). Third, regress those means on DTM following

$$
\overline{p_{D T M}^{e}}=\beta_{0}+\beta_{1} D T M+\mu
$$

where the per month term premium, $t p^{e}$, is equal to $\beta_{1} \times 365 / 12 .^{9}$ As Model 1 in Table 5 indicates, this procedure produces a constant average premium over the sample period equal to about 5.49 basis points per month.

Some caveats with this approach are noteworthy. The point estimate of $t p^{e}$ is sizeable, and the standard deviations of $p^{e}$ for each DTM are also large. For example, there are 111 observations in the October 4, 1988 to March 31, 2003 sample for which there are exactly 30 days to maturity. The mean difference between $\mathrm{r}^{\mathrm{fff}}{ }_{t, t+n}$ and $\bar{r}_{t+n}^{\text {eff }}$ is about 3.55 basis points, but the standard deviation is 16.76 basis points, and the range is -53.47 to 58.10 basis points. Exhibit 1 shows the upper and lower bounds corresponding to the one-standard deviation confidence interval around the mean for each DTM. Notably, the lower bound of the mean is always negative, even very close to expiration. ${ }^{10}$

Another caveat regards the fact that the estimate imposes the assumption that the term premium is linear in the time to expiration, but other functional forms of DTM of course relax this assumption. Table 5 also presents the regression results for a linear-log and a simple quadratic form of DTM, Models 2 and 3, respectively. According to the adjusted $\mathrm{R}^{2}$ values for

\footnotetext{
${ }^{8}$ The selection of the range from one to 150 days is of course arbitrary, as is the use of the first five federal funds futures contracts. However, this restriction is useful with respect to the calculation of the term premium in the next section that does not assume that forecast errors average to zero. (The survey data do not consistently include forecasts beyond 21 weeks.)

${ }^{9}$ One does not necessarily have to regress on the means. A similar regression of the individual calculations of $p^{e}$ produces the same estimate for $\beta$.

${ }^{10}$ This also reflects the notion that the term premium varies over time and is possibly negative during certain periods in the sample. Again, the issue of time variation is discussed in greater detail in the next section.
} 
Model 1 and Model 2, the linear specification clearly explains more variance than the linear-log alternative. However, the square to DTM from Model 3, which imposes that the term premium increases at an increasing rate with time to maturity, explains slightly more variance than the linear model. This result broadly fits the pattern in Table 3, in which the term premium (or bias) seems to increase with the futures forecast horizon.

Another way to examine the appropriateness of the assumption that the term premium increases linearly with time is to consider a simple piecewise-linear spline function. Model 4 is a simple regression on $\bar{p}_{D T M}^{e}$ assuming five knots approximately at each month to maturity including DTM $<31,31 \leq \mathrm{DTM}<61,61 \leq \mathrm{DTM}<91,91 \leq \mathrm{DTM}<121$, and $121 \leq \mathrm{DTM} \leq$ 150. The results suggest that the term premium is about 3.62 basis points within 30 days to maturity, but the estimate increases to 7.81 basis points per month between 120 and 150 days to maturity. This suggests that the constant slope estimate of 5.49 basis points per month from the linear specification in Model 1 might overestimate the per month term premium in the near term but underestimate the relation between the term premium and maturity further out the futures term structure.

\subsection{Daily Data: A Survey Proxy for Forecast Errors}

The preceding estimates all assume that $\varepsilon$ averages to zero over the sample. Some estimates of the term premium and its slope with respect to time to maturity seem greater than common priors, and one might suspect that positive forecast errors inform a considerable portion of these estimates. Indeed, perhaps the assumption of zero forecast errors is not only tenuous but also unnecessary given a wealth of survey evidence on policy expectations. Therefore, another 
calculation also assumes that the term premium is constant but relaxes the assumption that forecast errors average to zero and proxies for $\varepsilon$ using survey-based estimates of forecast errors.

Survey results suggest that forecast errors do not average to zero, even given over a decade of high-frequency data. As Exhibit 2 illustrates, the survey errors based on mean predictions from weekly Money Market Services (MMS) from January 1991 to March 2003 period are non-zero. ${ }^{11}$ Long-run errors, which range from 75 to 82 days to maturity until July 1997 and from 74 to 151 days to maturity thereafter, averaged about 13.8 basis points over the period (with a standard deviation of about 40.5 basis points). Also, short-run errors, which range from four to 54 days to maturity, averaged 2.0 basis points (with a standard deviation of 11.5 basis points). In particular, investors did not anticipate the extent of the 2001 easing and incorrectly expected significant tightening in 2002. While one cannot address the counterfactual, the increase in forecast errors is noteworthy considering greater volume in federal funds futures markets in recent years and the contention that increased transparency in Federal Reserve disclosure practices has allowed market participants to more accurately forecast policy changes (Poole and Rasche, 2000). ${ }^{12}$

In order to proxy $\varepsilon_{t^{+n}}$ with the weekly MMS data and therefore to inform (11), the forecast errors in Exhibit 2 must be expressed as basis points per month. This procedure closely reflects the estimates of $t p^{e}$, except at a weekly frequency given the conduct of the surveys. The steps are as follows. First, calculate the forecast errors from the surveys - the difference between the mean forecast value and the realized target - for each week to maturity (WTM) in the

\footnotetext{
${ }^{11}$ Weekly MMS survey data are available beginning in January 1991. Prior to August 1997, respondents predicted the target federal funds rate for one, two, and six maintenance periods ahead. Thereafter, they have forecasted the target following the next three FOMC meetings.

${ }^{12}$ Nevertheless, these forecast errors are still positive given data before these episodes from January 1991 through December 2000. During this period, long-run forecast errors averaged 6.1 basis points, and short-run errors averaged 0.8 basis points.
} 
sample ${ }^{13}$ which ranges from one to 21 weeks. Second, calculate the mean forecast error for each WTM. Third, regress the means of $\varepsilon$ on WTM following

$$
\bar{e}_{W T M}=\alpha_{0}+\alpha_{1} W T M+\mu,
$$

where the forecast error proxy, $\varepsilon_{t+n}$, is equal to $\beta \times 365 /(12 \times 7)$. As Model 1 in Table 6 indicates, given all available data from January 1991 through March 2003, $\varepsilon_{t+n}$ is equal to 5.37 basis points per month.

Given this result, one can therefore relax the assumption that $\varepsilon_{t+n}$ is equal to zero and solve for the ex ante premium directly following (11). The corresponding estimate of the average per month value of $f f f_{t}-e f f_{t+n}$ (or the term premium assuming zero forecast errors under the method outlined in Section 2.3) for the January 1991 - March 2003 period is 5.77 basis points. ${ }^{14}$ Therefore, the term premium using this method for the period is equal to $(5.77-5.37$ $=) 0.40$ basis points.

While this method usefully relaxes a stringent assumption, there are a number caveats, including some inherent reservations regarding survey data. For example, the analysis does not consider the possibility that survey respondents simply consult implied rates on federal funds (and eurodollar) futures contracts. If this is so, then the survey-based measure does not isolate the term premium. Also, the MMS survey does not have consistent respondents from week to week, and therefore variance in the central tendencies might not only reflect variance in policy expectations but also changes in the cross-section of respondents. In addition, survey respondents by construction only submit the central tendency of their forecast, but federal funds

\footnotetext{
${ }^{13}$ The results using survey medians instead of means are similar in magnitude and are available on request.

${ }^{14}$ Full results, including alternative function forms and the linear-piecewise estimation, for the January 1991 March 2003 period are available on request.
} 
futures rates additionally reflect the probability that investors attach to possible policy outcomes. Therefore, futures markets perhaps give a finer measure of policy expectations. Finally, survey respondents predict the target funds rate to prevail after a specific FOMC meeting, while futures rates are based on the expected average effective funds rate, which might deviate from the target, over the contract month.

But more specific to the calculations that culminate in (13), another issue is that considerably fewer observations inform the estimate of $\alpha_{1}$ in (13) vis-à-vis $\beta_{1}$ in (12) - 21 (weeks to maturity) versus 150 (days to maturity). This issue is an artifact of the weekly frequency of the surveys, but the variance of the mean forecast errors for each week to maturity are substantial, and as Exhibit 3 indicates, the lower bound of the one standard deviation confidence interval is not positive for any week to maturity. ${ }^{15}$ Also, similar to the calculation in the previous section, the survey-based measure assumes that the forecast error is a linear function of the length of the forecast horizon (time to maturity). As Table 6 indicates, the linear functional specification that informs the estimate (Model 1) fits the data better that either the linear-log (Model 2) or quadratic (Model 3) forms. But, the linear-piecewise spline function highlights the decline in survey forecast errors beyond 16 weeks. As Model 4 indicates, the coefficient for the knot for the 17 to 21 week forecast horizon is in fact negative, which questions the assumption that survey forecast errors increase linearly with the forecast horizon.

Finally, as Exhibit 3 shows, there is a downward kink in the function between 10 and 12 WTM. This is due to the fact that before August 1997, the survey polled respondents about the target one, two, and six maintenance periods ahead, instead of the three subsequent FOMC meetings. Therefore, the forecast error means for each WTM greater than 12 are taken from the

\footnotetext{
${ }^{15}$ For example, there are 211 observations for which there are 4 weeks to maturity in the complete sample. The mean forecast error for the 4-week forecast horizon is about 2.3 basis points, and the standard deviation is about 12.7 basis points.
} 
post-July 1997 period. Therefore, an estimate of the term premium using data since August 1997, when the survey began to poll expectations for the next three FOMC meetings, is perhaps a more valid indicator. During this period, the estimate of the average per month value of $r^{f f f}{ }_{t}-$ $\bar{r}_{t+n}^{e f f}$ is 6.33 basis points, and the MMS forecast error is 5.27 basis points per month. Therefore, the term premium is equal to 1.06 basis points per month for the August 1997 - March 2003 period. ${ }^{16}$

\section{Time-varying Term Premium Estimates}

The main caveat applicable to each of the four estimates in Section 2 is that they impose a constant term premium. Indeed, some evidence suggests the contrary. For example, all estimates from the previous section are somewhat sensitive to sample selection. As Exhibits 4-6 indicate, rolling 5-year calculations of both the term premium using monthly data and the per month term premium vary considerably, and the MMS survey-based measure of the per month term premium (Exhibit 6$)$ is often negative. ${ }^{17}$

To address this issue and relax the assumption associated with the expectations hypothesis, this section examines time-varying estimates that use the term structure of federal funds futures rates and briefly compares these results to estimates that use longer-dated eurodollar futures contracts (Sack, 2002).

\subsection{The Term-Structure of Implied Federal Funds Futures Rates on Near-dated Contracts}

This method focuses on near-term federal funds futures contracts and produces an estimate of the term premium based on a very simple identification of implied rates. In general,

\footnotetext{
${ }^{16}$ Full estimation results for the August 1997 through March 2003 period are available on request.

${ }^{17}$ The five-year rolling window somewhat compromises the assumption the forecast errors average to zero over the sample. But, this issue should not similarly affect the MMS-based estimate.
} 
this method uses the fact that there are more monthly federal funds futures contracts than FOMC meetings per year and assumes that the term premium increases linearly as the futures maturity lengthens. Consider the implied rate, $r^{f f f}$, on the February 2003 contract on, say, February 19, 2003, as in

$$
r_{F e b r u a r y}^{f f f}=\frac{d_{1}}{D_{1}} \bar{r}^{e f f}+\frac{d_{1}^{c}}{D_{1}} r_{t}^{t f f}+d_{1}^{c} T P
$$

where $d_{l}$ is the number of days that have transpired in the month; $D_{l}$ is the number of days in the month; $\bar{r}^{\text {eff }}$ is the cumulative average effective funds rate for the month; $d_{1}^{c}$ is the number of remaining days in the month; $r_{t}^{t f f}$ is the prevailing target federal funds rate, which investors presumably anticipate for the remainder of the month; and $T P$ is the term premium. In words, the futures rate reflects the cumulative average of the effective funds rate, market expectations for the target for the remainder of the month, and the term premium. Similarly, the implied rate on the March 2003 contract on February 19, 2003 follows

$$
r_{\text {March }}^{f f f}=\frac{d_{2 m}}{D_{2}} r_{t}^{t f f}+\frac{d_{2 m}^{c}}{D_{2}} r_{t+1}^{t f f}+\left(d_{1}^{c}+D_{2}\right) T P
$$

where $d_{2 m}$ is the number of days in the month before the next FOMC meeting (on March 18, 2003), $D_{2}$ is the number of days in the month, $d^{c}{ }_{2 m}$ is the number of days in the month after the FOMC meeting, and $r^{t f f} f_{t+1}$ is the expected target federal funds rate after the FOMC meeting.

Notably, using (14) and (15) one can use the two equations to solve for the two unknowns, $T P$ and $r_{t+1}^{t f}$. For example, the closing prices on both contracts imply that on February 19 the term premium was -3.1 basis points, and the expected federal funds rate after the March 18 FOMC meeting was 1.275 percent, which, given the prevailing target of 1.25 
percent, suggests that market participants attached about a 10 percent probability to a 25 basis points increase in the target at the meeting.

While this method usefully solves for expected federal funds rates and the term premium simultaneously and in real time, the historical time series of these estimates is quite volatile. Exhibit 7 presents the estimates given data from January 3, 1994 to March 31, 2003. Between two and five contracts are necessary to produce unique solutions for $T P$ and $r^{t f f}{ }_{t+1},{ }^{18}$ and the average term premium is 3.50 basis points per month, but the standard deviation is 125.15 basis points. Moreover, the estimates are less than zero for about 36 percent of the sample. A smoothed series based on monthly medians of daily values has a mean of 1.68 basis points and a standard deviation of 6.22 basis points. In short, the term premium might vary over time, but the variance of this particular estimate seems excessive.

The volatility might suggest that the simple identifications in (14) and (15) are not satisfactory. Futures rates perhaps embed not only expectations about policy and a term premium but also anticipations regarding idiosyncratic technical factors in the underlying funds market (Söderström, 2001). ${ }^{19}$ For example, the effective federal funds rate tends to trade firm relative to the target at the end of March, June, and September but soft relative to the target at year-end. ${ }^{20}$ Given that federal funds futures contacts settle on the average effective funds rate of the month, futures rates likely embed expectations for these (and other possible) effects. In addition, the identification of the front month contract following (14) assumes that the market expects the funds rate to trade at the target for the remainder of the month. This excludes the

\footnotetext{
${ }^{18}$ There is no consistent solution to the system for 11 percent of all possible trading days. For example, after the January 28-29, 2003 FOMC meeting, the January and February contracts produced inconsistent solutions for TP. ${ }^{19}$ Söderström (2001) controls for end of month and seasonal monthly effects in his examination of the predictive power of futures rates in the front-month contract.

${ }^{20}$ Market participants commonly attribute these effects to end of period, balance sheet window dressing.
} 
possibility that market participants price possible autocorrelation in deviations of the effective from the target funds rate.

To gauge the relative importance of these idiosyncratic effects, the following regression follows

$$
\left(r^{e f f}-r^{t f f}\right)_{t}=\beta_{0}+\sum_{i=1}^{n} \beta_{t-i}\left(r^{e f f}-r^{t f f}\right)_{t-i}+\sum_{j=1}^{m} \beta_{S, j} S_{j}+\mu
$$

where $r^{t f f}$ is the target funds rate, the lag length $n$ is set equal to eight, and $\mathbf{S}$ is the set of $m$ dummy variables for possible "special days" in the funds market, such as quarter-end effects and particular holidays, as well as historical episodes such as Y2K and September 11. If a given $\beta_{S, j}$ is statistically significant, then market participants might incorporate expectations for that factor ex ante in future rates. Also, if, say, $\beta_{t-1}$ is statistically significant, then investors might incorporate the previous trading day's deviations from the target in their expectations for the funds rate for the remainder of the month.

Turning to the results, Model 1 in Table 7 suggests that deviations from the target are serially correlated given all available data from January 3, 1994 through March 31, 2003. The first lag is clearly the largest in magnitude, although the eighth lag is also statistically significant, and fourth and sixth lags are negative and significant. In addition, the regression suggests that several calendar effects are statistically significant - including all quarter-ends; the first of all months; holidays such as July $4^{\text {th }}$, Thanksgiving, and Christmas; Treasury settlement days; ${ }^{21}$ tax

\footnotetext{
${ }^{21}$ These include the $15^{\text {th }}$ or the next business day of February, May, August, and November for Treasury securities auctioned at the mid-quarter refunding; the $15^{\text {th }}$ or next business day of January, April, July, and October for Treasury Inflation-indexed Securities; and the last trading day of the each month for monthly Treasury securities. The funds rate tends to trade firm when Treasury auctions or redemptions settle because of large payment flows.
} 
days; ${ }^{22}$ the final Wednesday of the two-week maintenance period; and Fridays. ${ }^{23}$ The results also indicate that the target traded soft just before 2000 and in the days after the terrorist attacks of September 11, 2001, as the Desk provided amble liquidity during both episodes, and that deviations from the target correlate positively with the target level.

Models 2-4 examine the stability of the estimates across three (arbitrary) sample divisions, including the January 1994 - December 1996, January 1997 - December 1999, and January 2000 - March 2003 sub-periods. Some of the significant factors from Model 1 are sensitive to sample selection, but others are notably robust. For example, the first lag is statistically significant in each sample, and the magnitude of the coefficient is greatest in the most recent sample, as Model 4 indicates. In addition, the second quarter-end, the first trading day of January and July, Treasury settlement days, and Fridays also have the same sign and are statistically significant across each sample.

In general, these results suggest that (14) and (15) might be under-specified, and an augmented system of equations might better capture the term premium and policy expectations, simultaneously solving for some factors that apparently correlate with persistent deviations from the target. Such a specification that incorporates the expected autocorrelation in deviations from the target as well as quarter and year-end effects, again circa February 19, might follow

$$
r_{\text {February }}^{f f f}=\frac{d_{1}}{D_{1}} \bar{r}^{\text {eff }}+\frac{d_{1}^{c}}{D_{1}} r_{t}^{t f f}+d_{1}^{c} T P+\rho e_{t-1}
$$

\footnotetext{
${ }^{22}$ These include the $15^{\text {th }}$ of next business day of March, June September, and December for corporate taxes; and the $15^{\text {th }}$ of next business day of January, April, June, and September. Large payment flows and potentially elevated Treasury cash balances tend to push the funds rate higher.

${ }^{23}$ These "special days" sometimes intersect, and the regressions do not isolate the separate impacts of overlapping effects.
} 


$$
\begin{gathered}
r_{\text {March }}^{f f f}=\frac{d_{2 m}}{D_{2}} r_{t}^{t f f}+\frac{d_{2 m}^{c}}{D_{2}} r_{t+1}^{t f f}+\left(d_{1}^{c}+D_{2}\right) T P+\frac{n_{2}}{D_{2}} Q E \\
r_{\text {April }}^{f f f}=r_{t+1}^{t f f}+\left(d_{1}^{c}+\sum_{i=2}^{3} D_{i}\right) T P \\
r_{\text {May }}^{f f f}=\frac{d_{4 m}}{D_{4}} r_{t+1}^{t f f}+\frac{d_{4 m}^{c}}{D_{4}} r_{t+2}^{t f f}+\left(d_{1}^{c}+\sum_{i=2}^{4} D_{i}\right) T P \\
r_{\text {June }}^{f f f} \frac{d_{5 m}}{D_{5}} r_{t+2}^{t f f}+\frac{d_{5 m}^{c}}{D_{5}} r_{t+3}^{t f f}+\left(d_{1}^{c}+\sum_{i=2}^{5} D_{i}\right) T P+\frac{n_{5}}{D_{5}} Q E \\
r^{f f f f}=r_{t+3}^{t f f}+\left(d_{1}^{c}+\sum_{i=2}^{6} D_{i}\right) T P,
\end{gathered}
$$

which is a system of six equations and six unknowns - TP; $r_{t f f}^{t f} r_{t+1}^{t f}$, the expected target after the May 6 FOMC meeting; $r_{t f f}^{t+3}$, the expected target after the June 24-25 FOMC meeting; $Q E$, the expected quarter-end effect for the end of March and June; ${ }^{24}$ and $\rho$, the weight that market participants attach to the difference between the effective and target federal funds rates on the previous trading day.

Given the closing prices for February 19, 2003, the term premium estimate was about 4.16 basis points, and the expected rate after the March 18 FOMC meeting was about 1.1029 percent, which implied that the market attached about a 59 percent probability to a 25 basis point reduction in the target at the meeting.

Turning to historical estimates, due to the fact that this method requires at minimum solutions for $T P, r_{t f f}^{t}, \rho$, and $Q E$ or the year-end effect (when applicable), there simply are fewer observations for which there is a system of equations (futures contracts) that produces unique solutions. In fact, only about 20 percent of trading days produce solutions for these unknowns,

\footnotetext{
${ }^{24}$ This system assumes that the quarter-end effects for March and June are equivalent, which is not wholly inconsistent with the empirical results in Table 7. There are infinitely many solutions to the system if the quarter end effects enter as separate variables.
} 
and between four and six contracts are necessary. The mean estimate of $T P$ for the sample is approximately zero (-0.09 basis points), with a standard deviation of about 12.28 basis points, and the estimates are less than zero for approximately 41 percent of the sample. While considerably less volatile than the estimates following (14) and (15), the results using the augmented decomposition are still considerably volatile - the smoothed series based on monthly medians has a standard deviation of 4.47 basis points (and a mean of 0.31 basis points).

Why are the ex ante estimates of the time-varying term premium so volatile? Again, the results in Table 7 suggest that there might be several factors - in addition to autocorrelation in deviations from the target and quarter-end effects - for which market participants formulate expectations. Therefore, (17) is probably also underspecified, as market participants perhaps price anticipated effects related to, say, Treasury settlement days or Fridays. This issue is somewhat intractable in the sense that there are more "special days" or idiosyncratic technical factors (variables) than contracts (equations) out the term structure. ${ }^{25}$

Furthermore, specifications (14) and (15), as well as equation system (17), do not allow for the prospect of a policy action before the upcoming FOMC meeting. Rather, they assume that the federal funds rate trades at the target until the next FOMC meeting. But, similar calculations that relax this assumption and treat the expected funds rate until the next FOMC meeting as an unknown similarly produce highly volatile estimates. The mean estimate of $T P$ for the $1994-2002$ sample is -9.2 basis points, with a standard deviation of about 367.11 basis points, and the estimates are less than zero for approximately 42 percent of the sample. The

\footnotetext{
${ }^{25}$ On possible alternative might be to proxy for market participants' expectations for each "special day" using the regression coefficients from Table 7. However, as Models 1-4 indicate, the estimates are somewhat sensitive to sample selection. Also, the framework of (17) is potentially useful because the term premium, policy expectations, and "special days" are endogenous.
} 
corresponding smoothed series based on monthly medians has a mean of 2.28 basis points and a standard deviation of 12.09 basis points.

\subsection{The Slope of the Eurodollar Futures Curve}

Again, this paper focuses on term premium estimates using near-term contracts, but this section briefly compares the time-varying estimate of the term premium with estimates based on implied rates on eurodollar futures that expire farther into the future. As Sack (2002) notes, the slope of the eurodollar futures curve, say, between four and five years ahead is almost always positive. Expectations of Federal Reserve policy strongly influence eurodollar futures contracts that expire within one to two years, but market participants likely do not forecast changes in the target four or five years ahead. Rather, at long horizons past the present business cycle, investors likely surmise that policy will remain steady. If in fact policy expectations level out, then the term premium will primarily influence eurodollar futures contracts beyond such a horizon. As Exhibit 9 illustrates, the first and second moments of the eurodollar term structure estimate are very intuitive. The mean based on daily data is approximately 1.67 basis points per month for the January 1994 - March 2003 sample, and the standard deviation is only about 0.87 basis points.

One might expect that the term premium at a long horizon might be positively correlated with the term premium at shorter horizons. But notably, this measure does not correlate closely with the estimates using the term structure of federal funds futures rates following (14) and (15). The correlation between the corresponding daily series is about 0.0077 , and the correlation between the corresponding smoothed series based on monthly medians is 0.0177 . Similarly, the daily and monthly correlation coefficients between the federal funds term structure method that 
incorporates quarter-ends and autocorrelation in deviations from the target (17) and the eurodollar yield curve series are only 0.0170 and -0.0569 , respectively.

\section{An Empirical Asset Pricing Approach: CAPM and APT}

Table 8 summarizes market participants expectations for the March 18, 2003 FOMC meeting circa February 19 under alternative calculations for the term premium, which range from positive to negative. Previous applications of, for example, the expectations hypothesis of the term structure or the efficient markets hypothesis only specify the presence but not the sign or magnitude of a term premium. This section briefly examines an alternative approach based on standard asset pricing theory, which not only suggests that implied rates on federal funds futures contracts include a premium but also broadly specifies the conditions under which the premium is positive or negative.

For example, in the absence of arbitrage, a financial asset $i$ with a net rate of return $R$ from period $t$ to period $t+n$ must in equilibrium satisfy

$$
E_{t}\left[\left(1+R_{t, t+n}\right) M_{t, t+n}\right\rfloor=1
$$

where $M$ is the stochastic pricing kernel (Cochrane, 2001, Campbell et al., 1997). Equation (18) further implies that investors require greater expected return, the lower the covariance between the expected return on the asset and the pricing kernel, following

$$
E_{t}\left[\left(1+R_{t, t+n}\right)\right]=\frac{1-\operatorname{cov}\left(1+R_{t, t+n}, M_{t, t+k}\right)}{E_{t}\left[M_{t, t+n}\right\rfloor}
$$


The size and magnitude of the risk premium depends on the covariance between expected returns on a long futures position and the pricing kernel. Therefore, in theory, the term premium can be positive or negative.

\subsection{Empirical Asset-Pricing Models}

For example, the capital asset pricing model (CAPM) of Sharpe (1964), Lintner (1965), and Black (1972) suggests that an asset has a positive risk premium if the ex ante covariance between the expected return on (a long position in) the asset and the expected return on total wealth is positive. Consider an empirical application to this research question following

$$
R^{f f f}-R^{f}=\alpha+\beta\left(R^{M}-R^{f}\right)+\varepsilon
$$

- where $R^{f f f}$ is the "return" on the long federal funds futures position, ${ }^{26} R^{f}$ is the return on the riskless asset, and $R^{M}$ is the return on market portfolio - the risk premium on the long position in federal funds futures is positive if $\beta>0$. Put differently, if the long position contributes to systematic, and notably not idiosyncratic, risk, then the risk premium is positive. This application of the CAPM suggests that investors are not compensated for risk or uncertainty related to monetary policy if they can diversify away such risk.

A positive term premium seems like a sensible prior under the CAPM. That is, an unexpected increase (decrease) in the target funds rate is generally expected to lower (increase)

\footnotetext{
${ }^{26}$ The return on a long federal funds position from $t$ (the beginning of the month) to $t+n$ (the end of the month) is approximated as$$
R_{t, t+n}^{f f f}=\frac{\bar{P}_{t+n}^{f f f}-P_{t}^{f f f}}{P_{t}^{f f f}}
$$

where $\bar{P}^{f f f}$ is the settlement price of the futures at $t+n$ (the end of the month), and $P^{f f f}$ is the price of the contract at time $t$ (at the beginning of the month). This calculation ignores the timing of marked-to-market payments within the month and suggests that the difference between $\bar{P}^{f f f}$ and $P^{f f f}$ is equal to the sum of marked-to-market payments over the month. Therefore, the return calculation implies that the reinvestment rate is zero.
} 
the return on the long futures position as the settlement price falls (rises). In turn, such tighter (looser) monetary policy lowers (boosts) stock prices and boosts (lowers) bond yields across the yield curve. ${ }^{27}$ In this scenario, the return on the long futures position declines (increases) with lower (higher) returns on stocks and bonds. The positive covariance, then, suggests that investors require a premium to be long federal funds futures contracts. Conversely under this scenario, investors pay a premium for short positions, which lower overall portfolio risk. Of course, if unexpected monetary policy changes do not affect asset prices, then the long futures position does not contribute to market portfolio variance (total wealth), and therefore neither long nor short positions in federal funds futures contracts require a premium. ${ }^{28}$

\subsection{Empirical Results:}

A simple empirical application suggests that the risk premium is not positive. Regressions of excess returns ${ }^{29}$ for the front month federal funds futures contract (from onemonth to maturity) on excess price returns on the market portfolio - a market-weighted portfolio of all NYSE stocks and the Lehman Brothers Aggregate U.S. Bond Index - generally suggest that $\beta \leq 0 .^{30}$ As Table 9, Model 1 suggests, $\beta$ is negative but statistically insignificant from zero

\footnotetext{
${ }^{27}$ Some long-run (monthly and quarterly) (Jensen et al., 1996) and short-run (Patelis, 1997) data generally support this view.

${ }^{28}$ In fact, some monthly and quarterly data suggest no correlation between monetary policy changes and stock returns and bond yields (Durham, 2003). Furthermore, to consider another alternative case, assume that the market reacts perversely to unexpected monetary policy moves. At least with respect to the stock market, the "forecast signal" story suggests that an unexpected increase in the funds rate signals that the Federal Reserve's outlook is more sanguine that the market's, and therefore stock prices rise. In this case, the expected return on the long futures position and the market portfolio are negatively correlated, which in turn implies that investors pay a premium to be long the asset.

${ }^{29}$ Returns on the Lehman Brothers Treasury Bills index and Ibbotson (2002) data on bill returns proxy for the riskless rate.

${ }^{30}$ The Roll (1977) critique is applicable, as always, but notably the weight on bond returns in the market proxy ranges from 30 to 53 percent of the total market value of the portfolio.
} 
given all available data from October 1988 through February 2003. ${ }^{31}$ Furthermore, as Exhibit 10 indicates, rolling 5-year (60-month) estimates of $\beta$, which follow standard empirical tests of the CAPM, similarly do not suggest that the term premium is positive. Among all possible rolling 5year periods from October 1988-September 1993 to April 1998 - March 2003, $\beta$ is never statistically significant and positive.

Of course, the CAPM is not the only applicable asset-pricing model. Therefore, Table 9 also includes regressions that incorporate some variables from arbitrage pricing theory (APT). Following Chen et al. (1986), these include monthly growth in industrial production, unexpected inflation, changes in expected inflation, ${ }^{32}$ the spread between corporate and Treasury bonds, and the slope of the yield curve. ${ }^{33}$ In short, Models 2-4, which considerably improve overall fit, suggest that returns on federal funds futures are positively related to monthly growth in industrial production and negatively related to unexpected inflation. ${ }^{34}$ Therefore, these results suggest that the term premium can be positive. (Changes in expected inflation, corporate spreads, and the term structure are not statistically significant across specifications.) But in general, this limited sensitivity analysis using APT variables suggests that the sign of the risk premium depends on the specification of the asset-pricing model.

\section{Summary}

\footnotetext{
${ }^{31}$ This contrasts with the results referred to in Krueger and Kuttner (1996), who use the S\&P 500 stock index exclusively in their proxy for the market portfolio from June 1989 through November 1994. They conclude that the positive $\beta$ partially explains the premium or positive bias on federal funds futures.

32 The monthly Michigan survey of one-year ahead inflation measures inflation expectations.

${ }^{33}$ Given the possibility that returns on federal funds futures are endogenously related to corporate spreads and the yield curve, Model 5 excludes these variables.

${ }^{34}$ This result suggests that given unexpected inflation, the Federal Reserve increases the target, which in turn lowers the return on federal funds futures.
} 
In summary, a growing number of studies suggest that federal funds futures more closely reflect near-term monetary policy expectations than other financial instruments. Nonetheless, the possible existence of a risk premium on these assets complicates the precise extraction of expectations regarding Federal Reserve policy. Therefore, the preceding analyses examine a number of possible estimates of the term premium with specific respect to implied rates on nearterm federal funds futures contracts and therefore the more immediate policy horizon.

Among the monthly and quarterly estimates that are consistent with the expectations hypothesis, calculations that assume that forecast errors average to zero over the sample produce sizeable point estimates. Also, the identification that relaxes the assumption of zero forecast errors and uses the MMS survey produces a result that is more consistent with common priors. But, some evidence suggests that the term premium varies over time. The method outlined in this paper using the term structure of near-dated federal funds futures contracts produces estimates that are rather volatile. Moreover, such estimates do not correlate closely with an alternative measure of the term premium using implied rates on eurodollar futures contracts that expire four to five years ahead. One can possibly attribute the volatility of the term premium estimate to numerous idiosyncratic technical factors in the underlying funds market - ex ante consideration of each possible factor simply produces infinitely many solutions for the term premium and expected federal funds rates.

To complicate matters further, an application of the CAPM suggests that the risk premium on federal funds futures is less than or equal to zero. However, APT better accounts for the variance in a measure of excess returns on federal funds futures and in general suggests that the sign and magnitude of the risk premium is sensitive to specification of the pricing kernel. All in all, while federal funds futures contacts might best reflect market expectations for Federal 
Reserve policy, alternative estimates of the magnitude and perhaps even the sign of the term premium suggest that precisely extracting the implied path of monetary policy is very difficult. 


\section{References}

Black, Fischer, 1972, “Capital Market Equilibrium with Restricted Borrowing," Journal of Business, vol. 45, 444-455.

Bomfim, Antulio, 2003, "Monetary Policy and the Yield Curve," Board of Governors of the Federal Reserve System," manuscript.

Campbell, John Y., Andrew W. Lo, and A. Craig MacKinlay, 1997, The Econometrics of Financial Markets, Princeton University Press.

Chen, Nai-fu, Richard Roll, and Stephen A. Ross, 1986, "Economic Forces and the Stock Market, Journal of Business, vol. 59, 383-403.

Cochrane, John H., 2001, Asset Pricing, Princeton University Press.

Goldman Sachs, 2001, "Message in the Market, Fixed Income Weekly Market Outlook" (April 20).

Durham, J. Benson, 2003, "Should Equity Investors 'Fight the Central Bank'?: The Effect of Monetary Policy on Stock Market Returns," Financial Analysts Journal, forthcoming.

Gürkaynak, Refet S., Brian Sack, and Eric Swanson, 2002, "Market-based Measures of Monetary Policy Expectations," Finance and Economic Discussion Series Working Paper, No. 40 (September), Board of Governors of the Federal Reserve System.

Jensen, Gerald R., Jeffrey M. Mercer, and Robert R. Johnson, 1996, "Business Conditions, Monetary Policy, and Expected Security Returns," Journal of Financial Economics, vol. 40, 213-237.

Krueger, Joel T. and Kenneth N. Kuttner, 1996, "The Fed Funds Futures Rate as a Predictor of Federal Reserve Policy,” Journal of Futures Markets, vol. 16, 865-879.

Lintner, John, 1965, "The Valuation of Risk Assets and the Selection of Risky Investments in Stock Portfolios and Capital Budgets," Review of Economic and Statistics, vol. 47, 13-37.

Moore, Jeff and Richard Austin, 2002, "The Behavior of Federal Funds Futures Prices over the Monetary Policy Cycle," Federal Reserve Bank of Atlanta Economic Review, (Second Quarter), 45-61.

Patelis, Alex D., 1997, “Stock Return Predictability and the Role of Monetary Policy," Journal of Finance, vol. 52 (December), 1951-1972.

Poole, William and Robert Rasche, 2000, "Perfecting the Market's Knowledge of Monetary Policy," Journal of Financial Services Research, vol. 18 (December), 255-98. 
Roll, Richard, 1977, “A Critique of the Asset Pricing Theory’s Test: Part I,” Journal of Financial Economics, vol. 4, 129-176.

Rudebusch, Glenn D., "Federal Reserve Interest-rate Targeting, Rational Expectations, and the Term Structure," Journal of Monetary Economics, vol. 35, 245-274.

Sack, Brian, 2002, "Extracting the Expected Path of Monetary Policy from Futures Rates," Finance and Economic Discussion Series Working Paper, No. 56 (December), Board of Governors of the Federal Reserve System.

Sharpe, William F., 1964, "Capital Asset Prices: A Theory of Market Equilibrium under Conditions of Risk," Journal of Finance, vol. 19, 425-442.

Söderström, Ulf, 2001, “Predicting Monetary Policy with Federal Funds Futures Prices," Journal of Futures Markets, vol. 21, 377-391. 
Table 1: Tests of the Expectations Hypothesis of the Term Structure Monthly Data on Term Federal Funds Rates, May 1993 - March 2003

$$
\frac{r_{n, t+1}^{t f f}-r_{n, t}^{t f f}}{2}=-p_{n, t+1}^{e}+\beta\left(r_{2 n, t}^{t f f}-r_{n, t}^{t f f}\right)+\frac{\varepsilon_{t+1}}{2}
$$

(1)

Dependent Variable:

\section{Independent Variable}

Long Rate $\left(\mathrm{r}^{\mathrm{fff}}{ }_{2, \mathrm{t}}\right)$ minus Short Rate $\left(\mathrm{r}^{\mathrm{fff}}{ }_{1, \mathrm{t}}\right)$

Long Rate $\left(\mathrm{r}_{4, \mathrm{t}}^{\mathrm{tff}}\right)$ minus Short Rate $\left(\mathrm{r}^{\mathrm{fff}}{ }_{2, \mathrm{t}}\right)$

Long Rate $\left(\mathrm{r}_{6, \mathrm{t}}^{\mathrm{tff}}\right)$ minus Short Rate $\left(\mathrm{r}_{3, \mathrm{t}}^{\mathrm{tff}}\right)$

Long Rate $\left(\mathrm{r}_{8, \mathrm{t}}^{\mathrm{tff}}\right)$ minus Short Rate $\left(\mathrm{r}_{4, \mathrm{t}}^{\mathrm{tff}}\right)$

Long Rate $\left(\mathrm{rff}^{\mathrm{tff}} \mathrm{t}\right)$ minus Short Rate $\left(\mathrm{r}_{5, \mathrm{t}}^{\mathrm{tff}}\right)$

Long Rate $\left(\mathrm{r}^{\mathrm{tff}}{ }_{12, \mathrm{t}}\right)$ minus Short Rate $\left(\mathrm{r}_{6, \mathrm{t}}^{\mathrm{fff}}\right)$

Constant

Observations

R-squared

Term Premium

t-statistic -- $\mathrm{H} 0 \beta=1$

Standard errors in parentheses

* significant at $5 \%$;* significant at $1 \%$
(2)

(3)

(4)

(5)

(6)

\begin{tabular}{|c|c|c|c|c|c|}
\hline $\begin{array}{c}1 / 2 \text { Forecast } \\
\text { of Change in } \\
\text { the Short } \\
\text { Rate }\left(\mathrm{r}_{1}{ }^{\text {tff }}\right)\end{array}$ & $\begin{array}{c}1 / 2 \text { Forecast } \\
\text { of Change in } \\
\text { the Short } \\
\text { Rate }\left(\mathrm{r}_{2}{ }^{\mathrm{t}}\right)\end{array}$ & $\begin{array}{c}1 / 2 \text { Forecast } \\
\text { of Change in } \\
\text { the Short } \\
\text { Rate }\left(\mathrm{r}_{3}{ }^{\mathrm{tff}}\right)\end{array}$ & $\begin{array}{c}1 / 2 \text { Forecast } \\
\text { of Change in } \\
\text { the Short } \\
\text { Rate }\left(\mathrm{r}_{4}{ }^{\mathrm{tff}}\right)\end{array}$ & $\begin{array}{c}1 / 2 \text { Forecast } \\
\text { of Change in } \\
\text { the Short } \\
\text { Rate }\left(\mathrm{r}_{5}{ }^{\mathrm{tff}}\right)\end{array}$ & $\begin{array}{c}1 / 2 \text { Forecast } \\
\text { of Change in } \\
\text { the Short } \\
\text { Rate }\left(\mathrm{r}_{6}{ }^{\mathrm{tff}}\right)\end{array}$ \\
\hline
\end{tabular}

0.997

$(0.064)^{* *}$

1.038
$(0.090)^{* *}$

1.088

$(0.122)^{* *}$

1.077

$(0.155)^{* *}$

0.953

$(0.181)^{* *}$

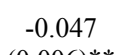

$-0.087$

$(0.013)^{* *}$

$-0.130$

$-0.189$

$(0.006)^{* *}$

117
0.53
0.087
0.417

116

0.41

0.130

0.721

0.047

$-0.050$

0.417

$(0.034)^{* *}$

$-0.222$

$(0.047)^{* *}$

$(0.204)^{* *}$

$-0.234$

114

0.20

0.222

$-0.262$

113

0.12

0.234

$-1.008$ 
Table 2: Tests of the Expectations Hypothesis of the Term Structure Monthly Data on Term Federal Funds Rates and Effective Funds Rates, May 1993 - March 2003

$$
\frac{1}{n} \sum_{i=0}^{n-1} r_{1, t+2+i}^{e f f}-r_{1, t}^{e f f}=-p_{n, t+n+1}+\beta\left(r_{n, t}^{t f f}-r_{1, t}^{e f f}\right)+\frac{\varepsilon_{n, t+n+1}}{n}
$$

$$
\begin{aligned}
& \text { Dependent Variable: } \\
& \text { Independent Variable } \\
& \text { 1-month } r^{\mathrm{tff}}{ }_{t} \text { minus } \mathrm{r}^{\mathrm{eff}}{ }_{\mathrm{t}} \\
& \text { 2-month } \mathrm{r}_{\mathrm{t}}^{\mathrm{tff}} \text { minus } \mathrm{r}^{\mathrm{eff}}{ }_{\mathrm{t}} \\
& \text { 3-month } \mathrm{r}_{\mathrm{t}}^{\mathrm{tff}} \text { minus } \mathrm{r}^{\mathrm{eff}}{ }_{t} \\
& \text { 4-month } \mathrm{r}_{\mathrm{t}}^{\mathrm{tff}} \text { minus } \mathrm{r}^{\mathrm{eff}}{ }_{\mathrm{t}} \\
& \text { 5-month } \mathrm{r}_{\mathrm{t}}^{\mathrm{tff}} \text { minus } \mathrm{r}^{\mathrm{eff}}{ }_{\mathrm{t}} \\
& \text { 6-month } \mathrm{r}_{\mathrm{t}}^{\mathrm{tff}} \text { minus } \mathrm{r}^{\mathrm{eff}}{ }_{\mathrm{t}} \\
& \text { Constant }
\end{aligned}
$$

\begin{tabular}{|c|c|c|c|}
\hline $\begin{array}{l}\text { month } \\
\mathrm{ff}_{-} \mathrm{reff}^{\mathrm{eff}}\end{array}$ & $\begin{array}{c}\text { 2-month } \\
r^{\text {eff }}-r^{\text {efff }}\end{array}$ & $\begin{array}{l}\text { 3-month } \\
r^{\text {eff }}-r_{t}^{\text {eff }}\end{array}$ & $\begin{array}{l}\text { 4-month } \\
\mathrm{r}^{\text {eff }}-\mathrm{r}_{\mathrm{t}}^{\mathrm{eff}}\end{array}$ \\
\hline
\end{tabular}

Standard errors in parentheses

* significant at 5\%; ** significant at $1 \%$
(1)
(2)

(3)

(4)

(5)

\subsection{3}

$(0.048)^{* *}$

0.901
$(0.078)^{* *}$

0.941

$(0.076)^{* *}$

$$
0.982
$$

$(0.076)^{* *}$

1.021

$(0.075)^{* *}$

$-0.169$

$-0.237$

$(0.017)^{* *}$

$(0.030)^{* *}$

$-0.279$

$(0.031)^{* *}$

$-0.321$

$(0.033)^{* *}$

$-0.365$

$(0.035)^{* *}$

1.061 $(0.077)^{* *}$ $-0.410$

$\begin{array}{cccccc}118 & 117 & 116 & 115 & 114 & 113 \\ 0.73 & 0.54 & 0.57 & 0.60 & 0.62 & 0.63 \\ 0.169 & 0.237 & 0.279 & 0.321 & 0.365 & 0.410 \\ -3.032 & -1.277 & -0.777 & -0.233 & 0.285 & 0.783\end{array}$


Table 3: Tests of Bias (Krueger and Kuttner, 1996)

Monthly Data, October 1988 - March 2003

$$
\bar{r}_{t+n, t}^{f f f}-\bar{r}_{t+n, t+n}^{e f f}=\alpha+\varepsilon_{t+n}
$$

$\begin{array}{lcccc} & (1) & (2) & (3) & (4) \\ & 1-\text {-month } & \text { 2-month } & \text { 3-month } & \text { 4-month } \\ \text { Constant } & \text { Horizon } & \text { Horizon } & \text { Horizon } & \text { Horizon } \\ & 0.050 & 0.098 & 0.159 & 0.234 \\ \text { Observations } & (0.010)^{* *} & (0.018)^{* *} & (0.026)^{* *} & (0.035)^{* *} \\ \text { R-squared } & 173 & 172 & 171 & 170 \\ \text { Bias (basis points) } & 0.00 & 0.00 & 0.00 & 0.00 \\ & 0.050 & 0.098 & 0.159 & 0.234\end{array}$

Standard errors in parentheses

+ significant at $10 \% ; *$ significant at $5 \% ; * *$ significant at $1 \%$ 
Table 4: Tests of Bias and Rationality (Krueger and Kuttner, 1996)

Monthly Data, October 1988 - March 2003

(1-month Horizon)

$$
\bar{r}_{t+n, t}^{f f f}-\bar{r}_{t+n, t+n}^{e f f}=\alpha+\beta X_{t-1}+\varepsilon_{t+n}
$$

\begin{tabular}{|c|c|c|c|c|c|c|c|c|c|c|c|c|c|c|}
\hline$\underline{\mathrm{X} \text { Variable }}$ & (1) & (2) & (3) & (4) & (5) & (6) & (7) & (8) & (9) & (10) & (11) & (12) & (13) & (14) \\
\hline Inflation Change (Monthly) & $\begin{array}{l}-5.50 \\
(5.01)\end{array}$ & & & & & & & & & & & & & \\
\hline Non-borrowed Reserves Growth & & $\begin{array}{c}0.31 \\
(0.33)\end{array}$ & & & & & & & & & & & & \\
\hline Total Reserves Growth & & & $\begin{array}{c}0.03 \\
(0.24)\end{array}$ & & & & & & & & & & & \\
\hline Base Growth & & & & $\begin{array}{c}2.57 \\
(1.81)\end{array}$ & & & & & & & & & & \\
\hline M2 Growth & & & & & $\begin{array}{l}-2.47 \\
(3.30)\end{array}$ & & & & & & & & & \\
\hline 1-year Note Spread over $\mathrm{r}^{\mathrm{ff}}$ & & & & & & $\begin{array}{c}0.01 \\
(0.02)\end{array}$ & & & & & & & & \\
\hline 30-year Bond Spread over rf & & & & & & & $\begin{array}{c}0.00 \\
(0.01)\end{array}$ & & & & & & & \\
\hline Funds Rate Change & & & & & & & & $\begin{array}{c}-0.16 \\
(0.05)^{* *}\end{array}$ & & & & & & \\
\hline FOMC Meeting Dummy & & & & & & & & & $\begin{array}{c}0.02 \\
(0.02)\end{array}$ & & & & & \\
\hline Tightening Dummy & & & & & & & & & & $\begin{array}{l}-0.05 \\
(0.02 * *\end{array}$ & & & & \\
\hline Unemployment Rate Change & & & & & & & & & & & $\begin{array}{c}0.02 \\
(0.07)\end{array}$ & & & \\
\hline Payroll Employment Growth & & & & & & & & & & & & $\begin{array}{l}-13.26 \\
(6.19)^{*}\end{array}$ & & \\
\hline UI Claims Change & & & & & & & & & & & & & $\begin{array}{c}0.00 \\
(0.00)^{*}\end{array}$ & \\
\hline Industrial Production Growth & & & & & & & & & & & & & & $\begin{array}{l}-1.73 \\
(2.02)\end{array}$ \\
\hline Constant & $\begin{array}{c}0.05 \\
(0.01)^{* *}\end{array}$ & $\begin{array}{c}0.05 \\
(0.01)^{* *}\end{array}$ & $\begin{array}{c}0.05 \\
(0.01)^{* *}\end{array}$ & $\begin{array}{c}0.04 \\
(0.01)^{*}\end{array}$ & $\begin{array}{c}0.06 \\
(0.02)^{* *}\end{array}$ & $\begin{array}{c}0.05 \\
(0.01)^{* *}\end{array}$ & $\begin{array}{c}0.04 \\
(0.02)^{* *}\end{array}$ & $\begin{array}{c}0.04 \\
(0.01)^{* *}\end{array}$ & $\begin{array}{c}0.03 \\
(0.02)\end{array}$ & $\begin{array}{c}0.07 \\
(0.01)^{* *}\end{array}$ & $\begin{array}{c}0.05 \\
(0.01)^{* * *}\end{array}$ & $\begin{array}{c}0.07 \\
(0.01)^{* *}\end{array}$ & $\begin{array}{c}0.05 \\
(0.01)^{* *}\end{array}$ & $\begin{array}{c}0.05 \\
(0.01)^{* *}\end{array}$ \\
\hline Obser & 17 & 17 & 17 & 17 & 17 & 17 & 17 & 17 & 17 & 17 & 17 & 17 & 17 & 173 \\
\hline R-squared & 0.01 & 0.01 & 0.00 & 0.01 & 0.00 & 0.00 & 0.00 & 0.06 & 0.01 & 0.03 & 0.00 & 0.03 & 0.03 & 0.00 \\
\hline
\end{tabular}

Standard errors in parentheses

* significant at $5 \%$; ** significant at $1 \%$ 
Table 5: Term Premium Regressions (Daily Futures Rates)

(October 1988 - March 2003)

$$
\overline{p_{t}^{e}}=\beta_{0}+\beta_{1} f(D T M)+\mu
$$

(3)

Days to Maturity

Log Days to Maturity

Days to Maturity Squared

Days to Maturity $<31$

$31<=$ Days to Maturity $<61$

$61<=$ Days to Maturity $<91$

$91<=$ Days to Maturity $<121$

$121<=$ Days to Maturity $<=150$

Constant

Observations

Adjusted R-squared

Term Premium per Month (Basis Points)

Term Premium per Month (Basis Points) $<31$ Days to Maturity

Term Premium per Month (Basis Points) $31 \leq$ Days to Maturity $<61$

Term Premium per Month (Basis Points) $61 \leq$ Days to Maturity $<91$

Term Premium per Month (Basis Points) $91 \leq$ Days to Maturity $<121$

Term Premium per Month (Basis Points) $121 \leq$ Days to Maturity $\leq 150$

Robust standard errors in parentheses

+ significant at $10 \%$; significant at $5 \% ; * *$ significant at $1 \%$
0.0018

$(0.0000)^{* *}$ 0.0697 $(0.0075)^{* *}$

0.00001 $(0.00000)^{* *}$

0.0012

$(0.0001)^{* *}$

0.0014

$(0.0001)^{* *}$

0.0018

$(0.0002)^{* *}$

0.0022

$(0.0002)^{* *}$

0.0026

$(0.0003)^{* *}$

$-0.0265$

$(0.0027)^{* *}$

$-0.1711$

$(0.0312)^{* *}$

0.0219

$(0.0019)^{* *}$

$-0.0058$

$(0.0026)^{*}$

150

150

0.667

150

0.956

150

0.967 


\section{Table 6: Forecast Error Regressions (MMS Survey)}

(January 1991 - March 2003)

$$
\bar{e}=\beta_{0}+\beta_{1} f(W T M)+\mu
$$

Weeks to Maturity

Log Weeks to Maturity

Weeks to Maturity Squared

Weeks to Maturity $<5$

$5<=$ Weeks to Maturity $<9$

$9<=$ Weeks to Maturity $<13$

$13<=$ Weeks to Maturity $<17$

$17<=$ Weeks to Maturity $<=21$

Constant

Observations

Adjusted R-squared

Forecast Error per Month (Basis Points)

Forecast Error per Month (Basis Points) $<5$ Weeks to Maturity

Forecast Error per Month (Basis Points) $5 \leq$ Weeks to Maturity $<9$

Forecast Error per Month (Basis Points) $9 \leq$ Weeks to Maturity $<13$

Forecast Error per Month (Basis Points) $13 \leq$ Weeks to Maturity $<17$

Forecast Error per Month (Basis Points) $17 \leq$ Weeks to Maturity $\leq 21$

Robust standard errors in parentheses

+ significant at $10 \%$; significant at $5 \% ; * *$ significant at $1 \%$
0.0124

$(0.0015)^{* *}$

0.0903

$(0.0140)^{* *}$

0.00051

$(0.00010)^{* *}$

0.0142

$(0.0026)^{* *}$

0.0127

$(0.0054)^{*}$

0.0127

(0.0092)

0.0278

$(0.0110)^{*}$

$-0.0232$

$(0.0060)^{* *}$

$\begin{array}{llll}-0.0057 & -0.0650 & 0.0505 & -0.0181\end{array}$

$\begin{array}{llll}(0.0114) & (0.0315)+ & (0.0139)^{* *} & (0.0083)^{*}\end{array}$

$\begin{array}{cccc}21 & 21 & 21 & 21 \\ 0.783 & 0.722 & 0.665 & 0.875\end{array}$

5.37

6.17

5.53

5.54

12.09

$-10.09$ 
Table 7: Daily Deviations from the Target Federal Funds Rate January 3, 2000- March 31, 2003

Sample:

Dependent Variable

Lagged Deviation from Target, 1 day(s)

Lagged Deviation from Target, 2 day(s)

Lagged Deviation from Target, 3 day(s)

Lagged Deviation from Target, 4 day(s)

Lagged Deviation from Target, 5 day(s)

Lagged Deviation from Target, 6 day(s)

Lagged Deviation from Target, 7 day(s)

Lagged Deviation from Target, 8 day(s)

End of Q1

End of Q2

End of Q3

End of Q4

1st of January

1st of July

1st of Remaining Months

Martin Luther King Day

Presidents Day

Memorial Day

July 4th

Labor Day

Columbus Day

Veterans Day

Thanksgiving

Christmas

Treasury Settlement Date

Tax Dates

Final Wednesday

Friday

December 27-31, 1999

September 11-20, 2001

Target Fed Funds Rate

Constant

Observations

R-squared

Standard errors in parentheses, * significant at 5\%; ** significant at $1 \%$

\begin{tabular}{|c|c|c|c|}
\hline $\begin{array}{c}1994-2003 \\
\text { (1) }\end{array}$ & $\begin{array}{c}1994-1996 \\
\text { (2) }\end{array}$ & $\begin{array}{c}1997-1999 \\
\text { (3) }\end{array}$ & $\begin{array}{c}2000-2003 \\
\text { (4) }\end{array}$ \\
\hline 0.222 & 0.186 & 0.246 & 0.342 \\
\hline$(0.019)^{* *}$ & $(0.032)^{* *}$ & $(0.031)^{* *}$ & $(0.031)^{* *}$ \\
\hline 0.003 & 0.071 & 0.018 & -0.098 \\
\hline$(0.019)$ & $(0.033)^{*}$ & $(0.032)$ & $(0.028)^{* *}$ \\
\hline 0.019 & 0.038 & -0.039 & -0.001 \\
\hline$(0.018)$ & $(0.031)$ & $(0.031)$ & $(0.028)$ \\
\hline-0.059 & -0.042 & -0.061 & -0.050 \\
\hline$(0.018)^{* *}$ & $(0.031)$ & $(0.030)^{*}$ & $(0.028)$ \\
\hline-0.015 & -0.013 & -0.014 & 0.023 \\
\hline$(0.018)$ & $(0.031)$ & $(0.030)$ & $(0.028)$ \\
\hline-0.040 & -0.038 & -0.060 & -0.044 \\
\hline$(0.018)^{*}$ & $(0.031)$ & $(0.030)^{*}$ & $(0.028)$ \\
\hline 0.013 & -0.013 & 0.032 & 0.048 \\
\hline$(0.018)$ & $(0.032)$ & $(0.030)$ & $(0.028)$ \\
\hline 0.076 & 0.088 & 0.036 & -0.042 \\
\hline$(0.018)^{* *}$ & $(0.031)^{* *}$ & $(0.028)$ & $(0.024)$ \\
\hline 0.266 & 0.198 & 0.715 & 0.089 \\
\hline$(0.054)^{* *}$ & $(0.116)$ & $(0.101)^{* *}$ & $(0.043)^{*}$ \\
\hline 0.452 & 0.416 & 0.815 & 0.124 \\
\hline$(0.054)^{* *}$ & $(0.116)^{* *}$ & $(0.083)^{* *}$ & $(0.050)^{*}$ \\
\hline 0.273 & 0.522 & 0.275 & -0.061 \\
\hline$(0.054)^{* *}$ & $(0.116)^{* *}$ & $(0.083)^{* *}$ & $(0.052)$ \\
\hline-0.443 & -0.123 & -0.603 & -0.515 \\
\hline$(0.054)^{* *}$ & $(0.117)$ & $(0.087)^{* *}$ & $(0.050)^{* *}$ \\
\hline 0.354 & 0.549 & 0.405 & 0.276 \\
\hline$(0.054)^{* *}$ & $(0.146)^{* *}$ & $(0.082)^{* *}$ & $(0.048)^{* *}$ \\
\hline 0.482 & 1.314 & 0.540 & 0.182 \\
\hline$(0.057)^{* *}$ & $(0.159)^{* *}$ & $(0.086)^{* *}$ & $(0.053)^{* *}$ \\
\hline 0.068 & 0.002 & 0.137 & 0.044 \\
\hline$(0.018)^{* *}$ & $(0.038)$ & $(0.028) * *$ & $(0.016)^{* *}$ \\
\hline 0.017 & 0.000 & -0.037 & 0.028 \\
\hline$(0.065)$ & $(0.000)$ & $(0.100)$ & $(0.044)$ \\
\hline-0.024 & 0.000 & -0.000 & -0.053 \\
\hline$(0.053)$ & $(0.116)$ & $(0.081)$ & $(0.050)$ \\
\hline-0.027 & 0.003 & -0.073 & -0.030 \\
\hline$(0.053)$ & $(0.115)$ & $(0.081)$ & $(0.050)$ \\
\hline-0.266 & -1.222 & -0.137 & 0.020 \\
\hline$(0.057)^{* *}$ & $(0.162)^{* *}$ & $(0.084)$ & $(0.053)$ \\
\hline 0.011 & 0.065 & -0.017 & 0.030 \\
\hline$(0.053)$ & $(0.116)$ & $(0.081)$ & $(0.050)$ \\
\hline-0.052 & -0.032 & -0.113 & -0.021 \\
\hline$(0.053)$ & $(0.116)$ & $(0.082)$ & $(0.050)$ \\
\hline 0.004 & -0.013 & 0.000 & -0.003 \\
\hline$(0.092)$ & $(0.198)$ & $(0.000)$ & $(0.061)$ \\
\hline 0.172 & 0.259 & 0.129 & 0.019 \\
\hline$(0.053)^{* *}$ & $(0.115)^{*}$ & $(0.081)$ & $(0.050)$ \\
\hline-0.172 & -0.141 & -0.330 & -0.071 \\
\hline$(0.053)^{* *}$ & $(0.117)$ & $(0.081)^{* *}$ & $(0.050)$ \\
\hline 0.192 & 0.262 & 0.171 & 0.118 \\
\hline$(0.013)^{* *}$ & $(0.029)^{* *}$ & $(0.023)^{* *}$ & $(0.012)^{* *}$ \\
\hline 0.134 & 0.097 & 0.232 & 0.066 \\
\hline$(0.026)^{* *}$ & $(0.058)$ & $(0.041)^{* *}$ & $(0.024)^{* *}$ \\
\hline 0.066 & 0.244 & -0.039 & 0.007 \\
\hline$(0.011)^{* *}$ & $(0.025)^{* *}$ & $(0.018)^{*}$ & $(0.010)$ \\
\hline-0.056 & -0.064 & -0.065 & -0.032 \\
\hline$(0.009)^{* *}$ & $(0.020)^{* *}$ & $(0.014)^{* *}$ & $(0.008)^{* *}$ \\
\hline-0.611 & 0.000 & -0.565 & 0.000 \\
\hline$(0.072)^{* *}$ & $(0.000)$ & $(0.067)^{* *}$ & $(0.000)$ \\
\hline-0.797 & 0.000 & 0.000 & -0.739 \\
\hline$(0.067)^{* *}$ & $(0.000)$ & $(0.000)$ & $(0.042)^{* *}$ \\
\hline 0.005 & -0.002 & 0.050 & 0.003 \\
\hline$(0.002)^{*}$ & $(0.009)$ & $(0.017)^{* *}$ & $(0.001)$ \\
\hline-0.023 & -0.003 & -0.252 & -0.009 \\
\hline$(0.011)^{*}$ & $(0.048)$ & $(0.092)^{* *}$ & $(0.007)$ \\
\hline 2305 & 747 & 749 & 809 \\
\hline 0.38 & 0.38 & 0.56 & 0.61 \\
\hline
\end{tabular}


Table 8

Market Implied Probabilities (as of market close, February 19, 2003)

25 Basis Point Reduction in the Target at the March 18 FOMC Meeting Various Term Premium Assumptions

\begin{tabular}{|c|c|c|c|}
\hline & Basis Points & $\begin{array}{c}\text { Federal } \\
\text { Funds } \\
\text { Futures }\end{array}$ & \\
\hline$\underline{\text { Term Premium Method }}$ & per Month & $\underline{\text { Contract(s) }}$ & Probability \\
\hline (No Term Premium) & 0.00 & Apr. & $20.00 \%$ \\
\hline Constant: Forecast Errors Average to Zero (August 1998 - March 2003) & 6.33 & Apr. & $77.47 \%$ \\
\hline Constant: MMS Survey (August 1998 - March 2003) & 1.06 & Apr. & $29.66 \%$ \\
\hline Time-varying: (14) and (15) & -3.10 & Feb.-Apr. & $-10.00 \%$ \\
\hline Time-varying: (17) & 4.16 & Feb.-Apr. & $58.84 \%$ \\
\hline Time-varying: Eurodollar Futures Slope (four to five years out) & 3.92 & Apr. & $56.05 \%$ \\
\hline
\end{tabular}


Table 9: CAPM and APT

Federal Funds Futures Excess Returns: October 1988 through February 2003 (One Month to Maturity)

\begin{tabular}{|c|c|c|c|c|}
\hline & (1) & (2) & (3) & (4) \\
\hline Market Portfolio Excess Return & $\begin{array}{c}-0.013 \\
(0.008)\end{array}$ & & $\begin{array}{l}-0.003 \\
(0.008)\end{array}$ & $\begin{array}{l}-0.009 \\
(0.007)\end{array}$ \\
\hline Industrial Production, monthly growth & & $\begin{array}{c}0.146 \\
(0.036)^{* *}\end{array}$ & $\begin{array}{c}0.146 \\
(0.036)^{* *}\end{array}$ & $\begin{array}{c}0.158 \\
(0.035)^{* *}\end{array}$ \\
\hline Unexpected Inflation & & $\begin{array}{c}-0.063 \\
(0.018)^{* *}\end{array}$ & $\begin{array}{c}-0.063 \\
(0.018)^{* *}\end{array}$ & $\begin{array}{c}-0.061 \\
(0.018)^{* *}\end{array}$ \\
\hline Change in Expected Inflation & & $\begin{array}{c}0.056 \\
(0.057)\end{array}$ & $\begin{array}{c}0.056 \\
(0.058)\end{array}$ & $\begin{array}{c}0.075 \\
(0.057)\end{array}$ \\
\hline Risk Premium & & $\begin{array}{l}-0.034 \\
(0.031)\end{array}$ & $\begin{array}{l}-0.029 \\
(0.034)\end{array}$ & \\
\hline Term Structure & & $\begin{array}{c}-0.033 \\
(0.017)+\end{array}$ & $\begin{array}{l}-0.030 \\
(0.019)\end{array}$ & \\
\hline Constant & $\begin{array}{c}-0.422 \\
(0.019)^{* *}\end{array}$ & $\begin{array}{c}-0.465 \\
(0.020)^{* *}\end{array}$ & $\begin{array}{c}-0.464 \\
(0.020)^{* *}\end{array}$ & $\begin{array}{c}-0.456 \\
(0.019)^{* *}\end{array}$ \\
\hline Observations & 173 & 173 & 173 & 173 \\
\hline R-squared & 0.02 & 0.23 & 0.23 & 0.21 \\
\hline Durbin-Watson Statistic & 0.59 & 0.85 & 0.86 & 0.91 \\
\hline
\end{tabular}


Exhibit 1: (12), Constant Term Premium (Zero Forecast Errors): January 1989 - January 2003

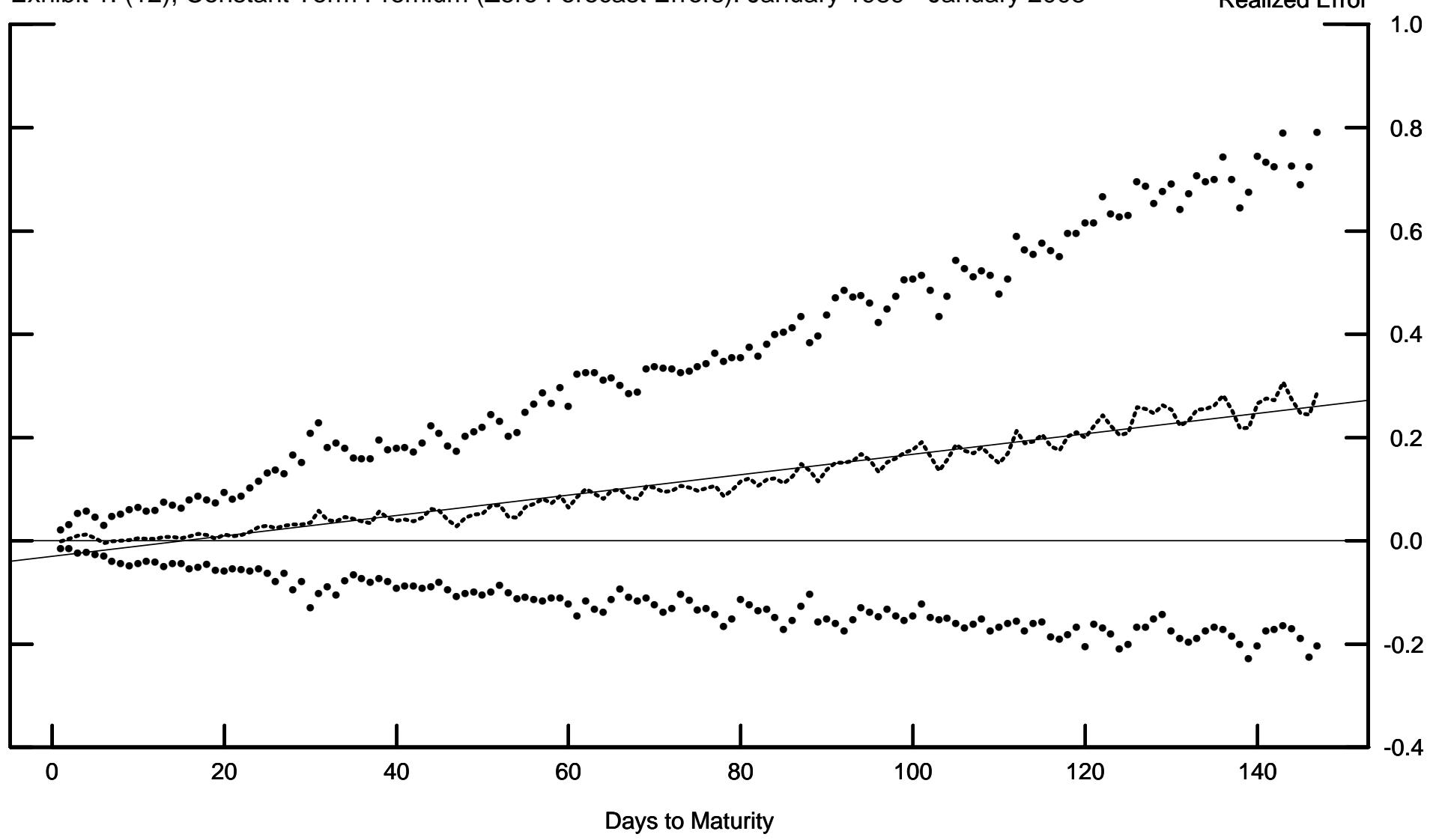

Exhibit 2: MMS Forecast Errors: January 1994 - March 2003

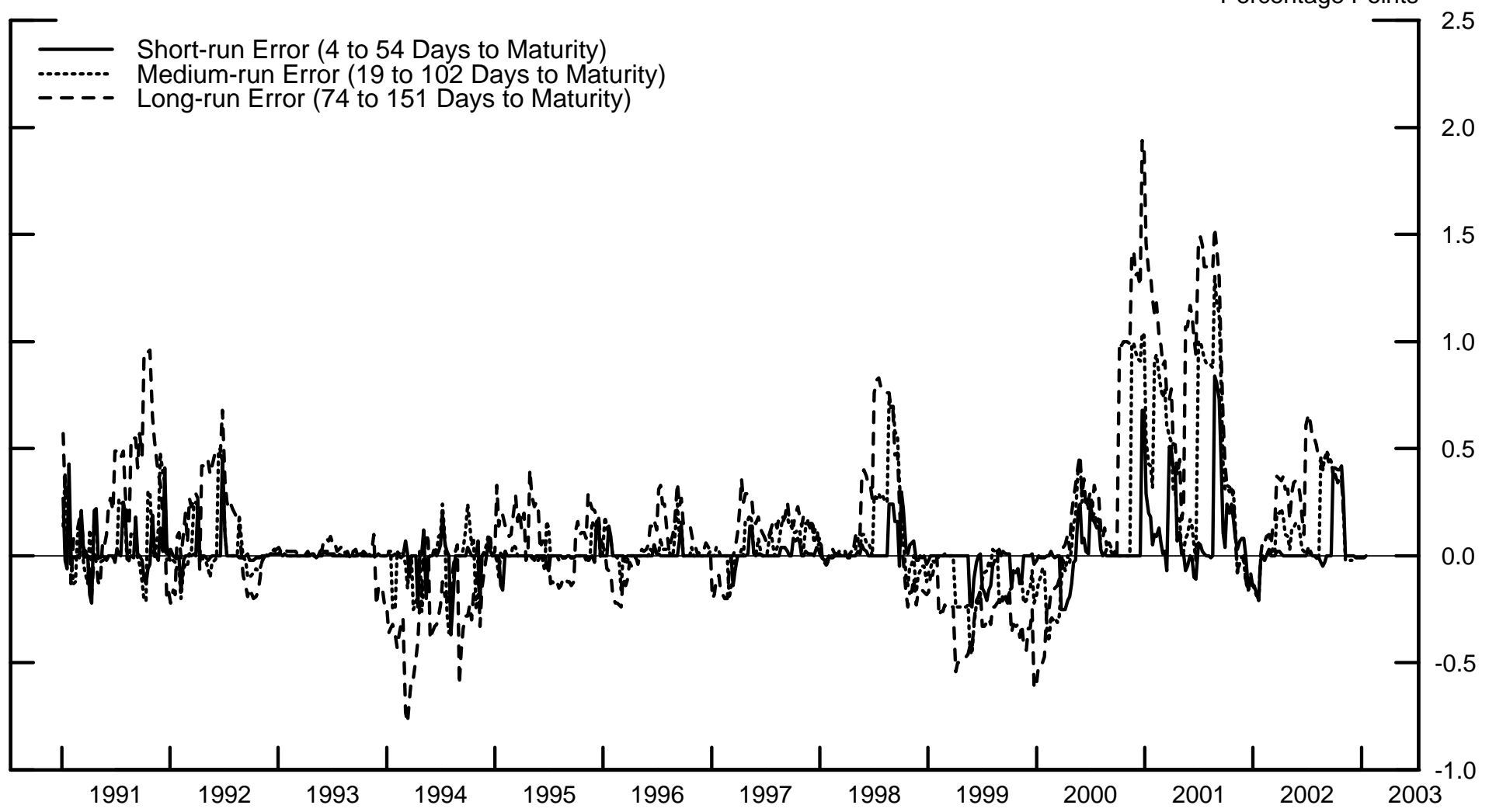


Exhibit 3: (13), MMS Survey-based Premium: January 1991 - March 2003

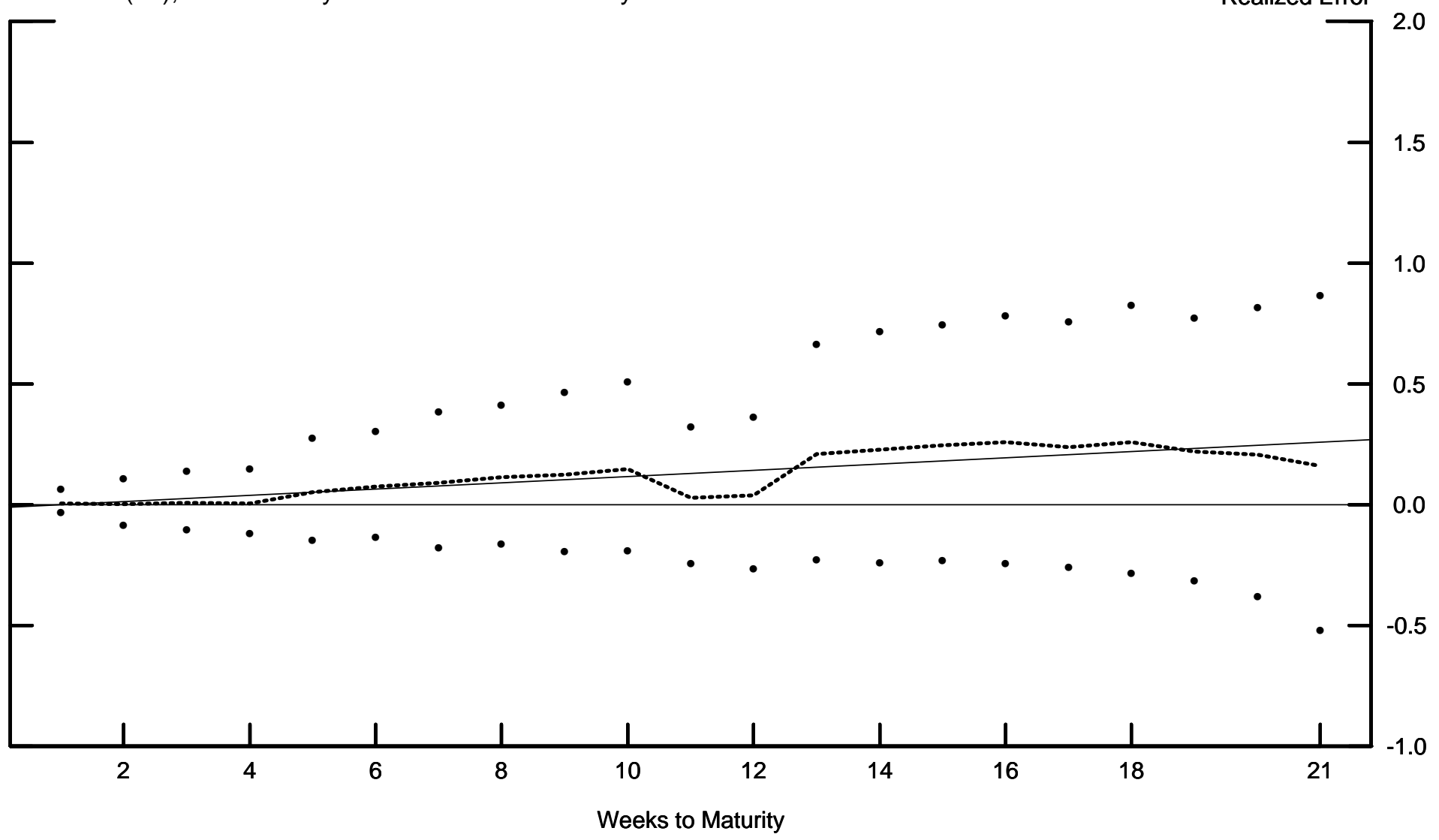

Exhibit 4: Monthly Rolling 5-year Constant Risk Premium: Expectations Hypothesis, 6/93-5/98 -- 4/98-3/03

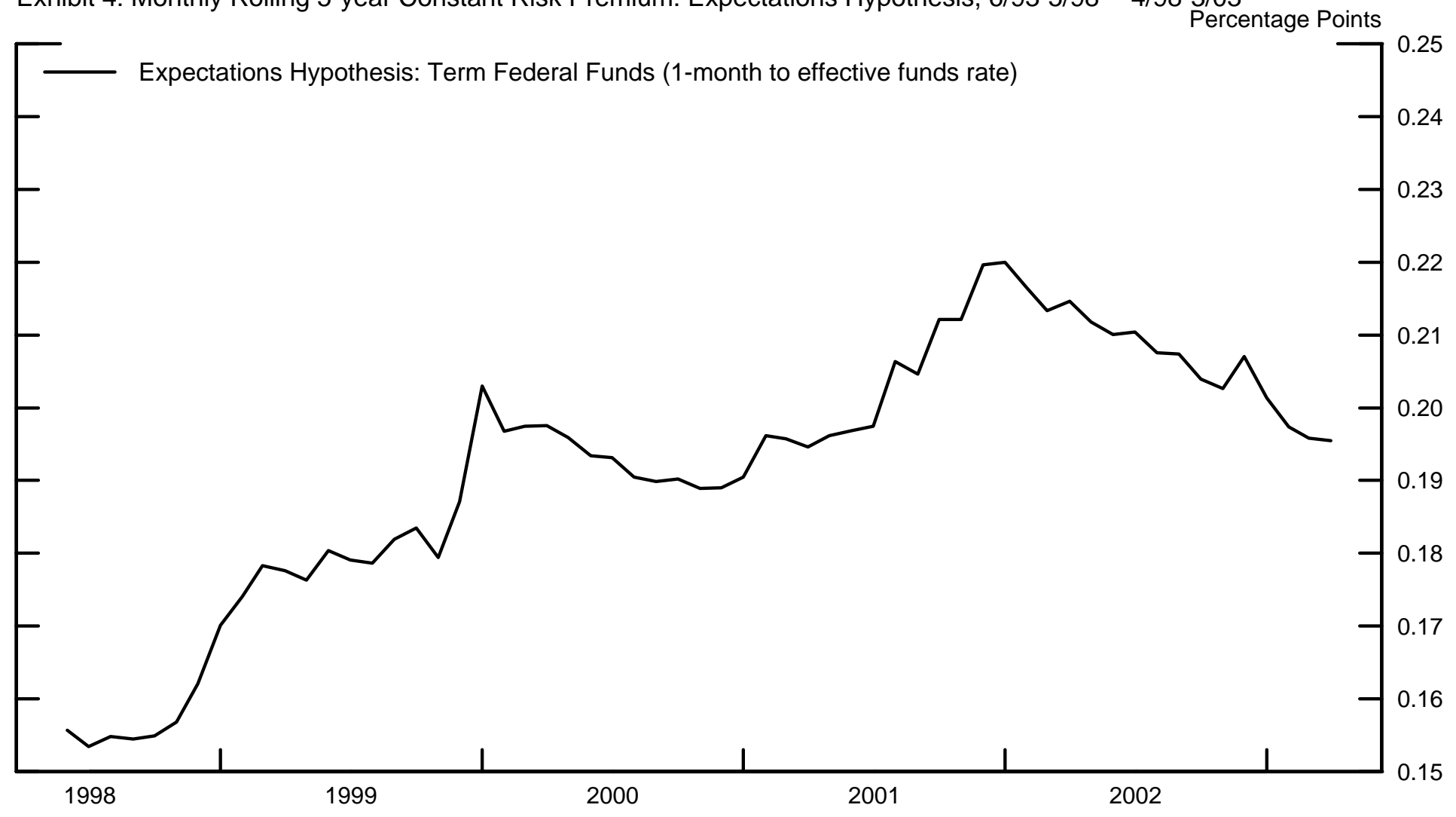




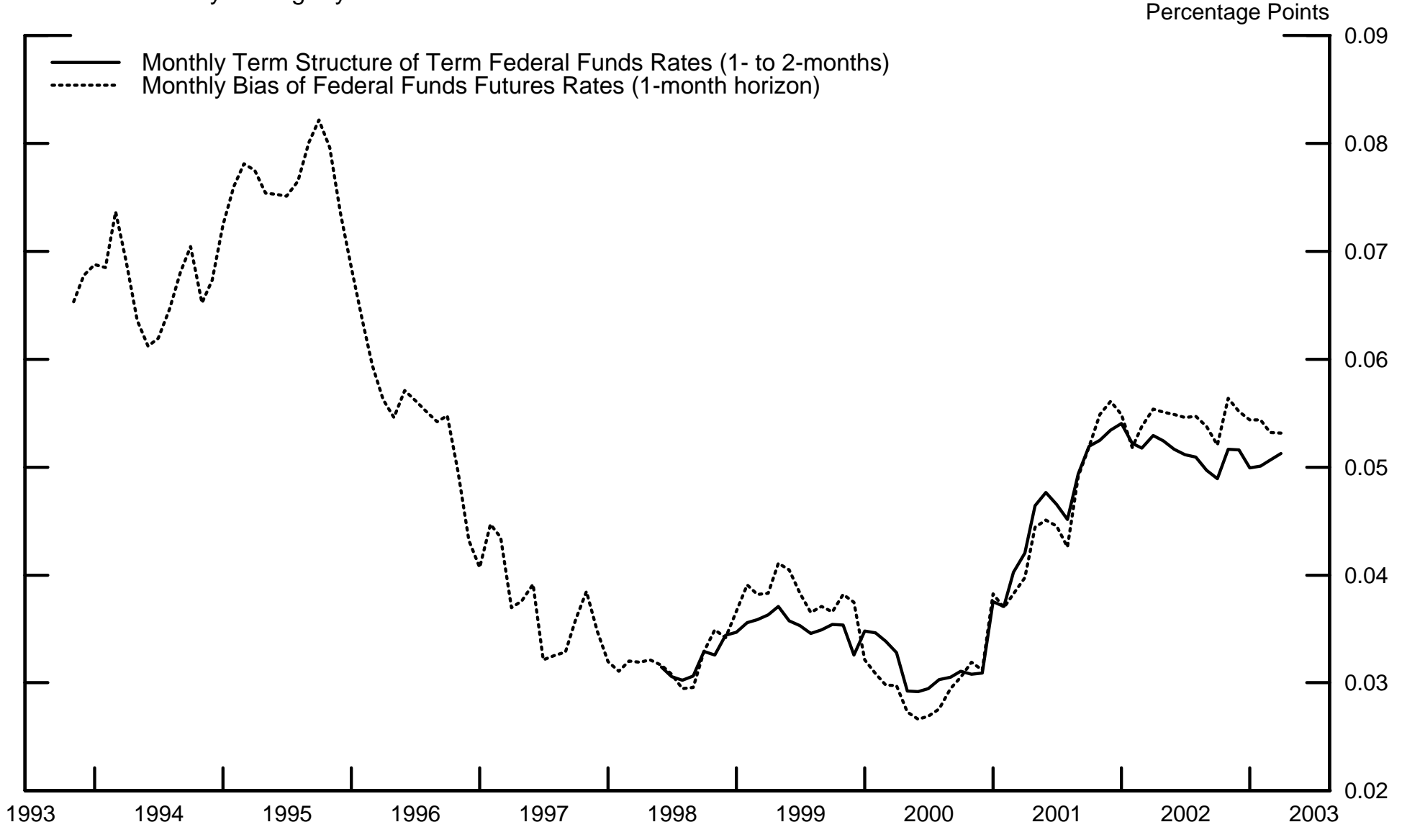

Exhibit 6: Monthly Rolling 5-year Constant Term Premium: October 1993 - March 2003

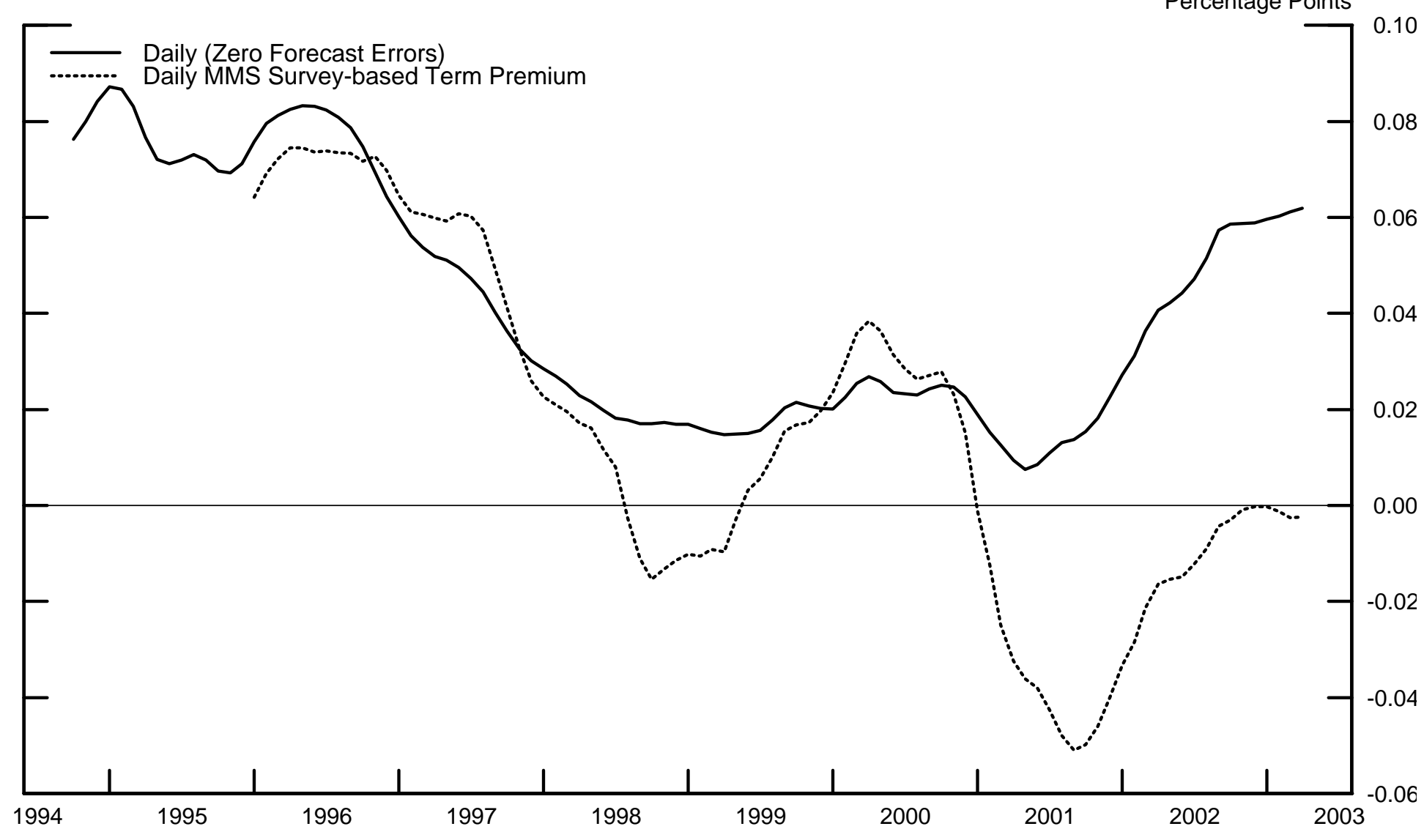


Exhibit 7: Time-varying Term Structure Term Premium, (8) and (9): Jan. 1994 - Mar. 2003

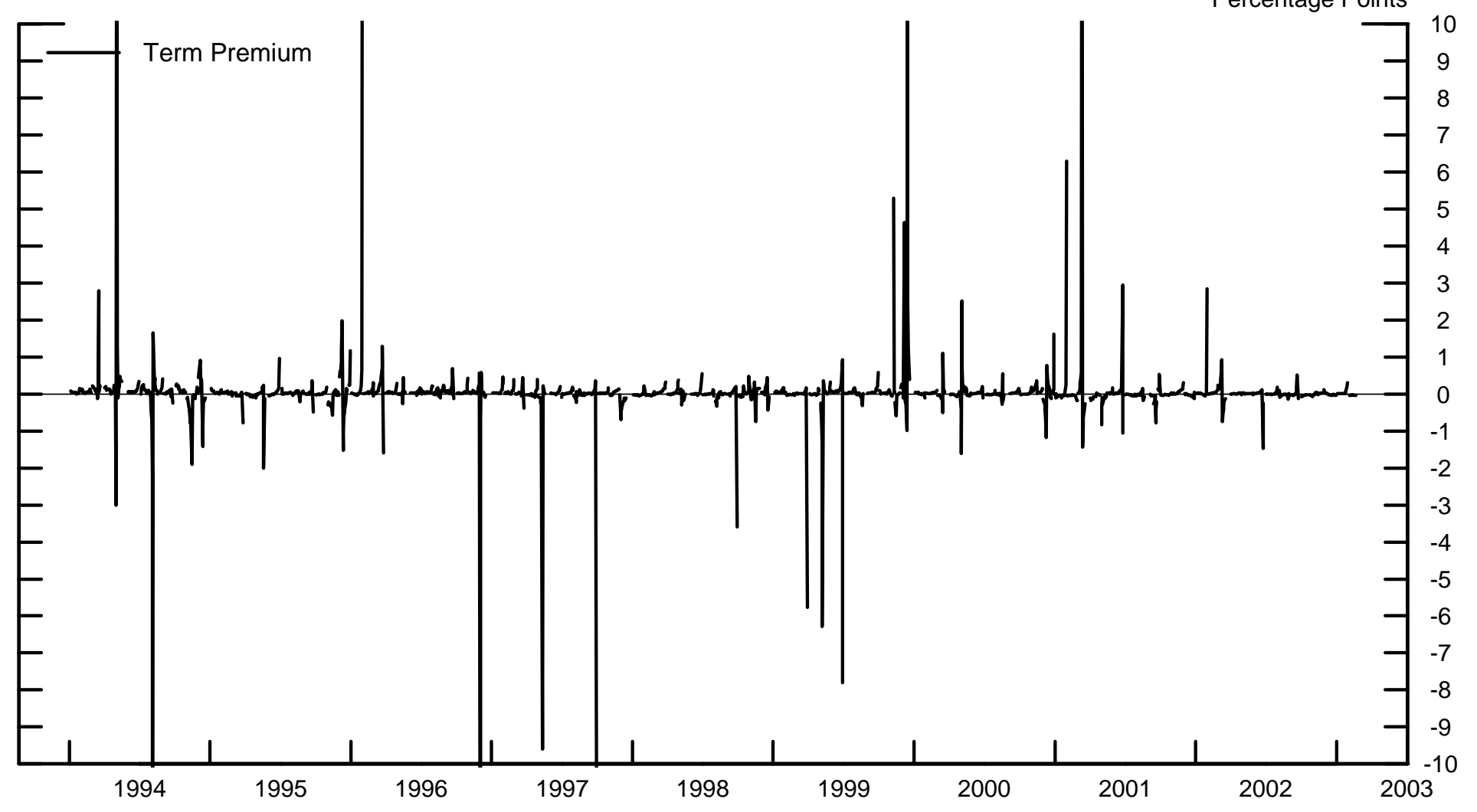

Exhibit 8: Time-varying Term Structure Term Premium, (11): Jan. 1994 - Jan. 2003

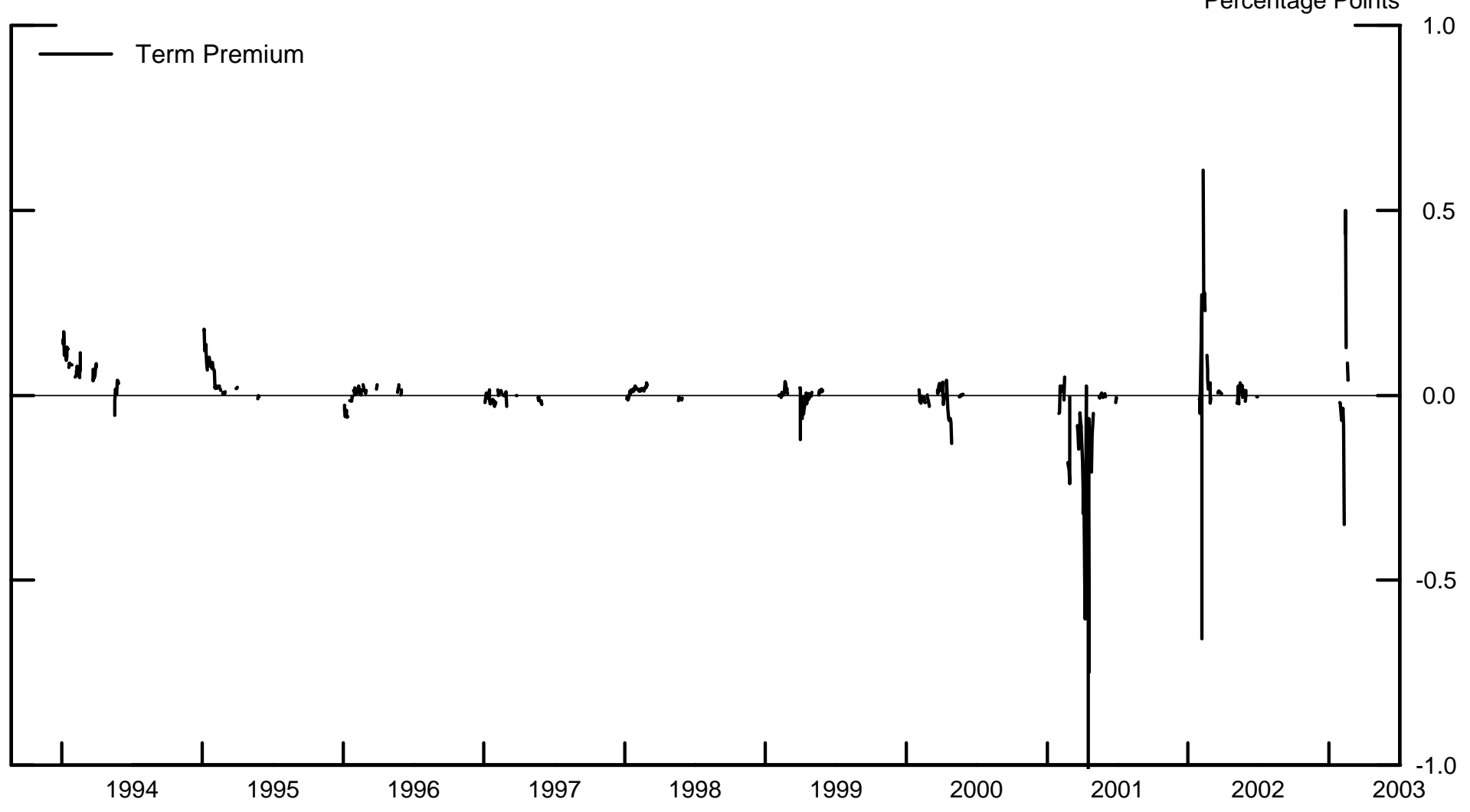


Exhibit 9: Time-varying Eurodollar Term Structure Term Premium: Jan. 1994 - Mar. 2003

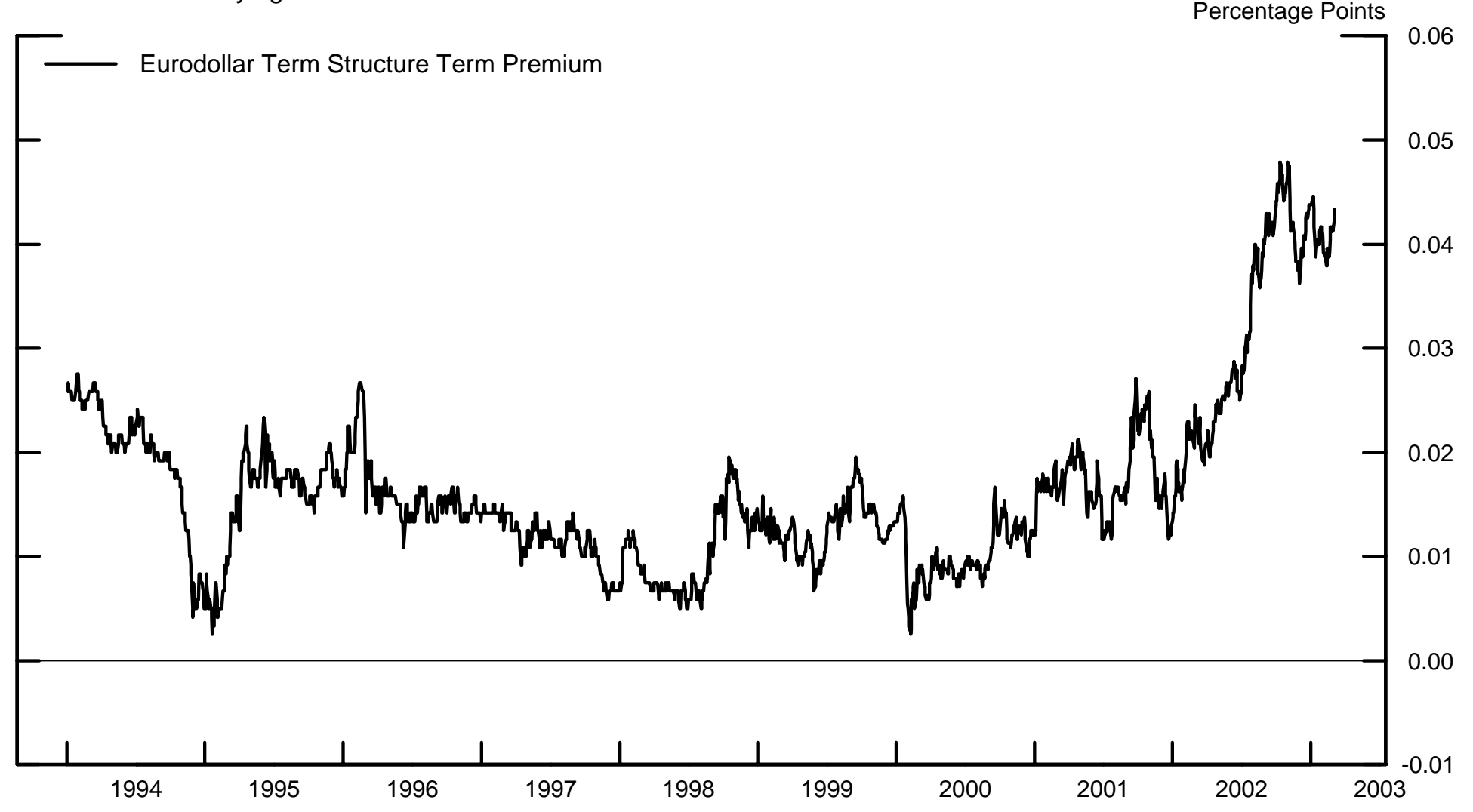

Exhibit 10: Rolling 5-year Federal Funds Futures Beta: Sep. 1993 - Mar. 2003

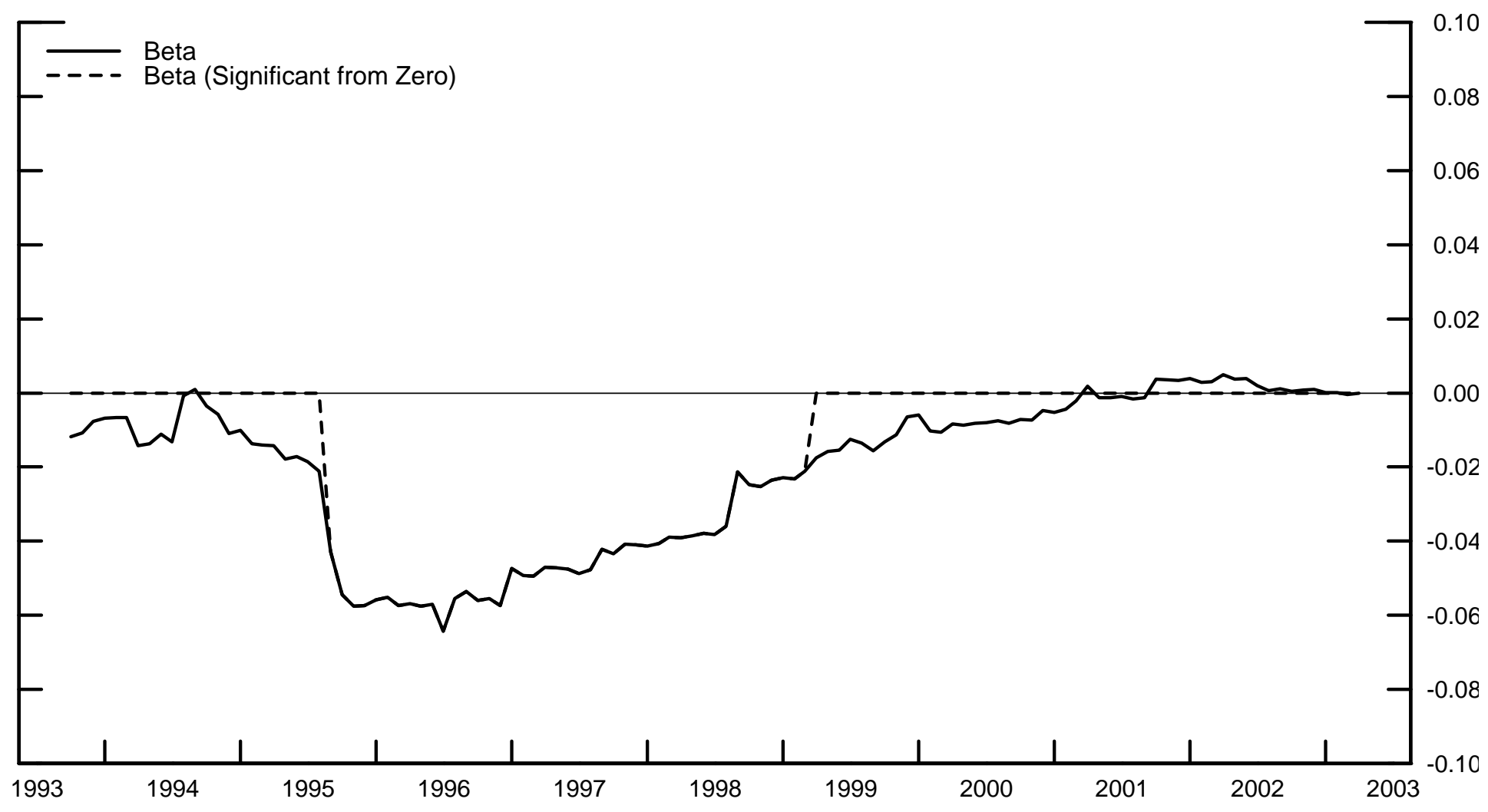

